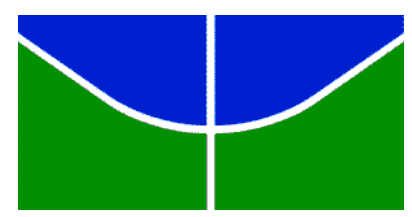

UNIVERSIDADE DE BRASÍLIA

FACULDADE DE COMUNICAÇÃO

PROGRAMA DE PÓS-GRADUAÇÃO

\title{
As Representações das Populações Indígenas na TV Brasil nas Perspectivas da Pluralidade e Diferença Cultural
}

Luísa Martins Barroso Montenegro

Trabalho apresentado à Banca Examinadora de Exame de Dissertação, como requisito para obtenção do grau de Mestre em Comunicação.

Linha de pesquisa: Políticas de Comunicação e de Cultura.

Orientadora: Prof. ${ }^{a}$ Dra. Elen

Cristina Geraldes 
Brasília (DF), Março de 2017

Luísa Martins Barroso Montenegro

As representações das populações indígenas na TV Brasil nas perspectivas da pluralidade e diferença cultural

Exame de dissertação de Mestrado avaliado pela seguinte Banca Examinadora:

Profa. Dra. Elen Cristina Geraldes

Universidade de Brasília - Faculdade de Comunicação

Profa. Dra. Dácia Ibiapina da Silva

Universidade de Brasília - Faculdade de Comunicação

Profa. Dra. Regina Lúcia Alves de Lima

Universidade Federal do Pará - Faculdade de Comunicação

Profa. Dra. Nelia Rodrigues Del Bianco

Universidade de Brasília - Faculdade de Comunicação 
Ficha catalográfica elaborada automaticamente pela Biblioteca Central da UnB, com os dados fornecidos pelo(a) autor(a)

M777r

Martins Barroso Montenegro, Luísa

As representações das populações indígenas na TV Brasil nas perspectivas da pluralidade e diferença cultural / Luísa Martins Barroso

Montenegro; orientadora Elen Cristina Geraldes. -- Brasília, 2017. $150 \mathrm{p}$.

Dissertação (Mestrado - Mestrado em Comunicação) -- Universidade de Brasília, 2017.

1. TV pública. 2. TV Brasil. 3. Populações indígenas. 4. Representações. 5. Pluralidade e diferença cultural. I. Geraldes, Elen Cristina, orient. II. Título. 
Jornalpe ojê'e opaicha olê'e

Tevepê ojê'e opaicha onê'e Oikuakwê hina oi hikwai ko oñomi Bom dia, boa tarde, ndo je'ei ko ape avape Soke agwatá.

(No jornal fala várias coisas

A TV mostra várias coisas A verdade existe só que eles escondem Bom dia, boa tarde não se fala para um índio Mas caminhamos.)

Brô MC's, Koangagua 
À minha mãe, meu exemplo de mulher e luta, pelo amor incondicional e por tudo que fez $\mathrm{e}$ sacrificou para que eu pudesse chegar a esse momento.

Ao meu marido Alexandre, companheiro de lutas e sonhos, por todo o amor e suporte. Nosso time é imbatível.

A todas as pessoas que resistem, diariamente, a violências e opressões, e àquelas que lutam para tornar o mundo um lugar mais justo, pelo fôlego de nadar contra a maré. 


\section{Agradecimentos}

Dois anos. Muitas aulas, muitas leituras, muitas noites acordada, muitas manhãs chuvosas na UnB. Muitas reuniões, muito envolvimento. Muito mundo para abraçar. Mais de quarenta horas assistindo toda a programação sobre indígenas na TV Brasil: desenhos, documentários, reportagens. Meses escrevendo.

A jornada é árdua, o caminho é íngreme e sinuoso, mas é o percurso que nos torna as pessoas que somos. E, neste percurso, nunca estive sozinha. Dizem que, na academia, caminhamos nas costas de gigantes, mas essa não foi minha experiência. Em minha jornada acadêmica, eu caminhei ao lado de guerreiras, e é a essas mulheres que devo minha gratidão.

Em primeiro lugar, meu agradecimento à professora Elen Geraldes, que me pegou pela mão no começo da estrada, tantos quilômetros atrás. Elen, que é orientadora, amiga, confidente, parceira na academia e na vida. Sua luz é um norte em minha caminhada.

À querida professora Janara Sousa, que também me acompanha desde o começo da jornada. Agradeço o carinho, a amizade, o suporte e incentivo. Você sempre foi uma inspiração como pesquisadora e mulher. Essa conquista também é sua.

À estimada professora Dácia Ibiapina, agradeço pelo acolhimento na pósgraduação, pela parceria nos estudos culturais e nas lutas, pela perspectiva criteriosa e não convencional. Sua contribuição foi essencial a este trabalho.

À querida professora Nelia Del Bianco, gratidão por toda à dedicação ao Programa de Pós-Graduação em Comunicação da Universidade de Brasília. Em especial, obrigada pelas lições valiosas na disciplina "Seminários de Pesquisa I", essenciais para este trabalho. Embora esteja sempre próxima, sua ausência é muito sentida nos corredores da FAC.

À gentil professora Regina Lima, agradeço a generosidade em aceitar o convite para participar de minha banca. Sua trajetória na radiodifusão pública é uma inspiração e sua contribuição na qualificação também moldou este trabalho.

Às maravilhosas amigas Natália Oliveira e Vanessa Negrini, sempre juntas nessa caminhada. É uma honra dividir tantas lutas e conquistas com vocês. Um agradecimento especial à Vanessa, que embelezou este trabalho com seus conhecimentos avançados em Microsoft Word. E um muito obrigada a Mateus Negrini, nosso companheiro de aventuras. 
$\mathrm{Na}$ jornada da vida, toda a minha gratidão às minhas famílias, por todo o carinho, paciência, amor e torcida. Amo todos vocês. Agradeço às três mulheres que são minha sustentação, o centro do meu mundo, e a quem devo tudo o que sou: minha avó Carmelita, minha mãe KK e minha irmã Fátima. Vocês são uma grande inspiração em minha vida.

Ao meu pai, David, agradeço por todo o carinho e amor, e pela paciência de responder (e incentivar!) os meus porquês. Devo muito de meu gosto pela leitura, imaginação e natureza questionadora a você. Obrigada por sempre me incentivar a ser uma pessoa melhor.

À minha madrasta, Hiderlene, e ao meu padrasto, Alberto, muito obrigada por me acolherem em suas famílias. À Hiderlene, agradeço os irmãos maravilhosos e o exemplo de caridade que me inspira a ser, eu mesma, mais engajada. Ao Alberto, agradeço o exemplo de caráter e tudo que faz por minha mãe e irmã. É uma satisfação fazer parte da família de vocês.

A todas as mulheres da família Barroso, agradeço pelo exemplo de força e determinação. Ao meu avô, Nilo Barroso, agradeço por me ensinar o valor do trabalho árduo e persistência. À família Montenegro, minha gratidão por toda a torcida e carinho. À família Burnett, muito obrigada por me acolherem como a uma filha.

Agradeço também às amigas e amigos que, com paciência, me viram cada vez menos nesses últimos dois anos de caminhada. Vocês, com suas trajetórias pessoais, são inspirações para mim. Bruno, um irmão de pais diferentes, que me ensinou que ter coragem não é sinônimo de não ter medo; Cris, melhor amiga da mesma cidade, empreendedora e apaixonada; Luciana, melhor amiga da cidade diferente, que foi para o interior da Bahia defender quem não pode arcar com defesa; Helena, companheira de tambor, cuja alegria e persistência contagiam; Luísa, que divide comigo um nome e um desejo de mudar o mundo; Lucas, que se mudou para o sertão para tornar o mundo mais justo; Elisa, um exemplo de dedicação, ética de trabalho e amizade; Gustavo, cuja força e determinação sempre me impressionam; Priscila, André e Rafa, pela dedicação a salvar gente. Vocês são demais.

Por fim, meus agradecimentos vão para a pessoa que, nos últimos doze anos, é meu porto seguro, meu melhor amigo, namorado e companheiro: meu marido, Alexandre. Essa jornada não teria sido possível sem o seu amor, apoio e paciência. Muito obrigada por me acalmar, por me fazer rir, por me levantar nos momentos difíceis 
e sempre estar lá, em minha torcida. Em geral, agradecimentos são clichê, mas nós somos o maior clichê do universo. É um privilégio amadurecer ao seu lado. 


\section{RESUMO}

O presente trabalho propõe-se a analisar as representações das populações indígenas na TV Brasil, no período de 01/01/2008 a 31/12/2015, nas perspectivas da pluralidade e diferença cultural. O objetivo geral é resgatar e analisar as representações das populações indígenas na TV Brasil, apontando limites e possibilidades para contemplar diferença e pluralidade. Os objetivos específicos são conceituar pluralidade e diferença na radiodifusão pública; discutir as missões da radiodifusão pública no que tange à sua programação no tratamento da temática dos povos indígenas; apontar diferenças e semelhanças no período analisado; estabelecer a frequência das representações de pessoas indígenas e apontar onde se concentram; destacar o local dos indígenas na programação da EBC; compreender a quem se destinam os conteúdos relacionados às temáticas indígenas; apontar por quem são produzidos tais conteúdos e quais temáticas abordam; estabelecer se as representações das populações indígenas mudaram com o passar dos anos; e sugerir mudanças na atual programação e nas ações empreendidas pela TV Brasil. Para tanto, a pesquisa recuperou os conteúdos com temáticas indígenas no período, por meio das palavras-chave "índio", "indígena", "cultura indígena" e "populações indígenas", na ferramenta de busca da página da TV Brasil. Concluiu-se que, em sua maioria, as representações das populações indígenas são positivas e apresentam as populações como agentes, pessoas complexas e sujeitos de direitos. As abordagens são favoráveis às causas indígenas e mostram as questões do ponto de vista dessas populações. No entanto, embora tenha inovado nas representações, no período analisado a TV Brasil não conseguiu quebrar a logica hegemônica que coloca o indígena no local do outro. A programação da TV Brasil tem indígenas como pauta, mas não consegue integrar essas pessoas como público-alvo ou produtores; apresenta programações sobre indígenas, mas não para indígenas ou por indígenas.

PALAVRAS-CHAVE: TV Pública. TV Brasil. Populações Indígenas. Representações. Pluralidade e Diferença Cultural. 


\section{LISTA DE QUADROS}

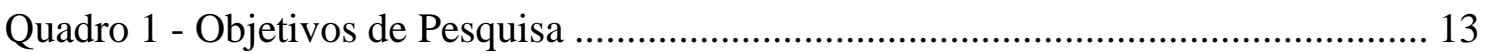

Quadro 2 - Indicadores de Pluralidade e Diferença...................................................... 46

Quadro 3 - Principais marcos históricos das populações indígenas ............................. 54

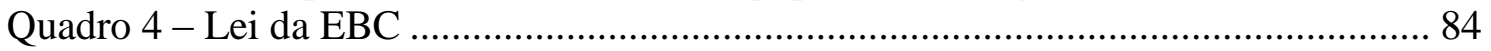

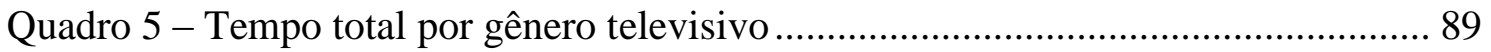

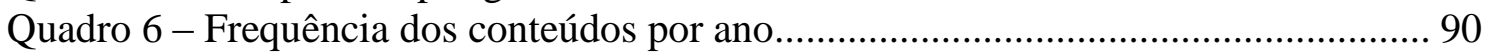

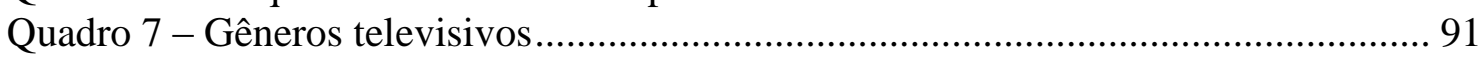

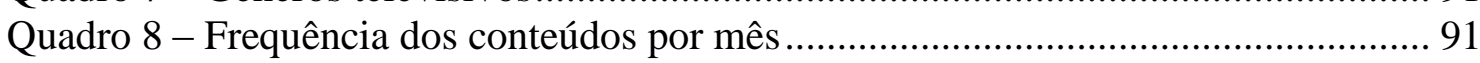

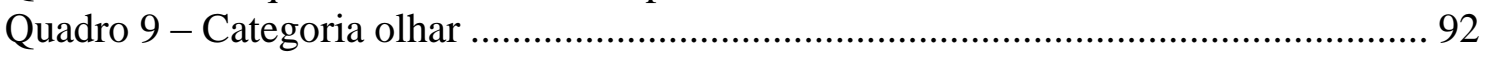

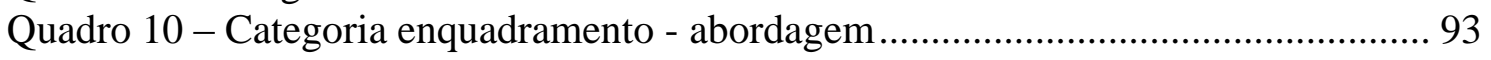

Quadro 11 - Categoria enquadramento - papel ......................................................... 94

Quadro 12 - Categoria abordagem - papel por ano ................................................. 95

Quadro 13 - Distribuição do papel de vítima por gênero televisivo ............................. 96

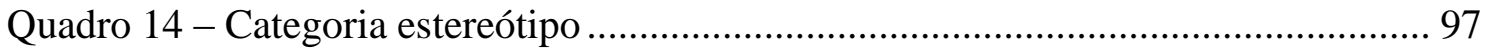

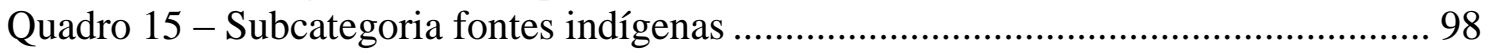

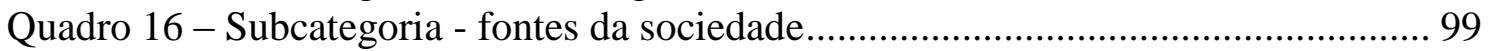

Quadro 17 - Distribuição da categoria fontes ........................................................ 100

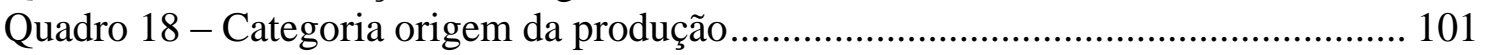

Quadro 19 - Papel nas produções não-indígenas ....................................................... 102

Quadro 20 - Frequência da categoria estereótipo nas produções não-indígenas ......... 102

Quadro 21 - Fontes nas produções não-indígenas ................................................... 103

Quadro 22 - Fontes da sociedade nas produções não-indígenas................................. 104

Quadro 23 - Fontes indígenas nas produções não-indígenas ...................................... 105

Quadro 24 - Representações positivas por gênero televisivo ................................... 110

Quadro 25 - Frequência dos gêneros televisivos por ano ......................................... 114

Quadro 26 - Frequência da abordagem por ano ....................................................... 115

Quadro 27 - Frequência do estereótipo por ano .......................................................... 115 


\section{LISTA DE FIGURAS}

Figura 1 - Nuvem de palavras - todos os termos..................................................... 116

Figura 2 - Nuvem de palavras - temas de 2011 a 2013 ............................................ 119

Figura 3 - Nuvem de palavras - assuntos dos conteúdos com temática indígena ....... 121 


\section{SUMÁRIO}

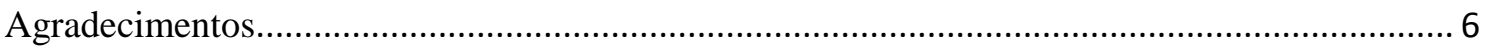

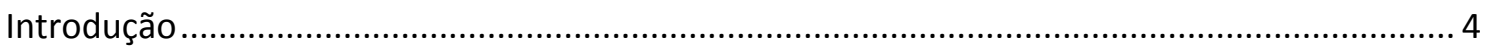

PARTE UM - MOENDY

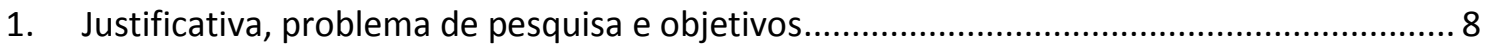

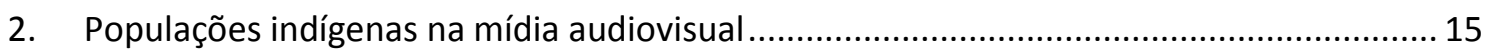

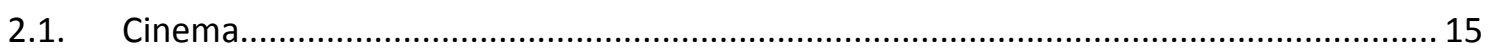

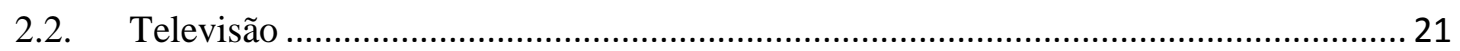

PARTE DOIS - XE R-APÉ

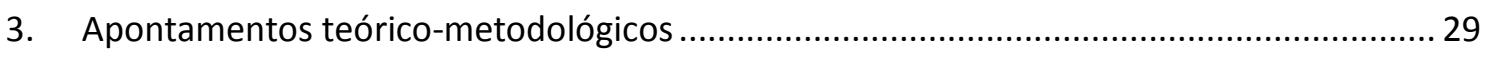

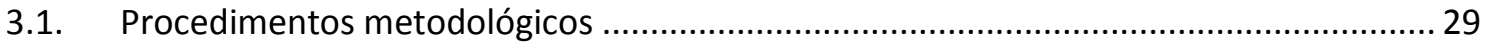

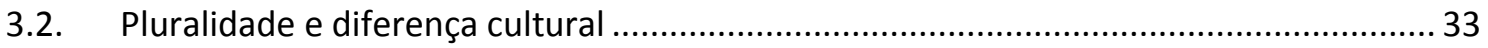

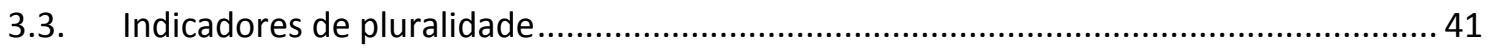

3.3.1. Origem da produção...................................................................................... 41

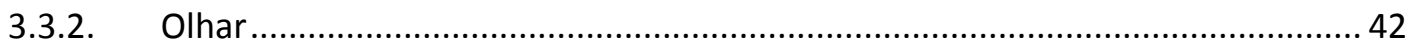

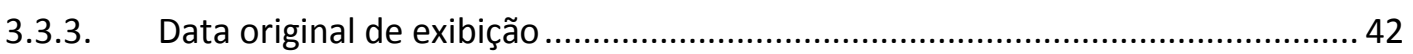

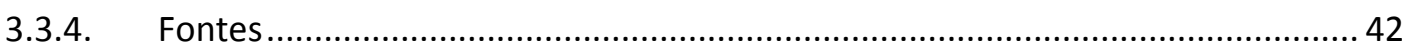

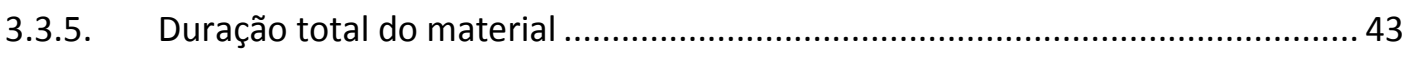

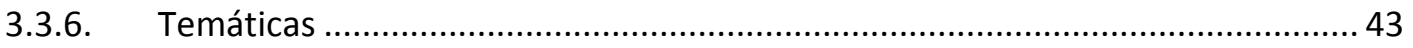

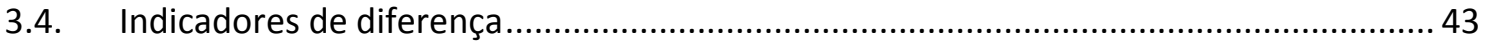

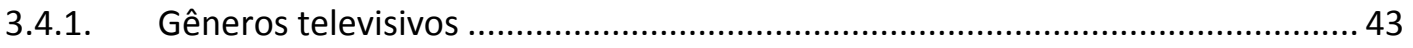

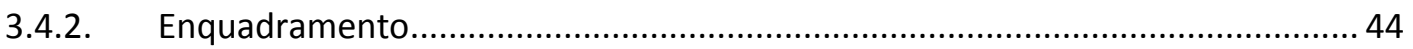

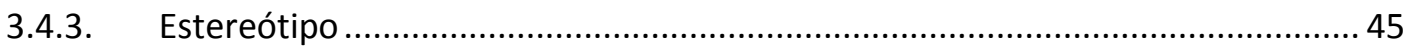

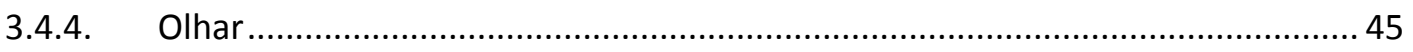

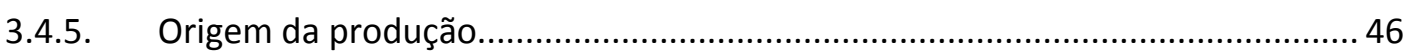

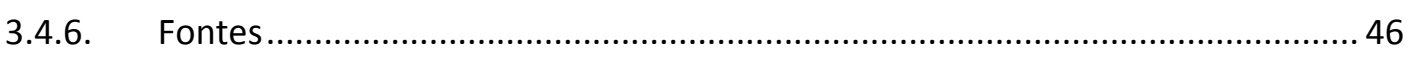

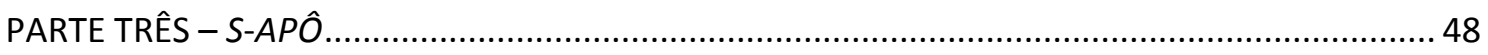

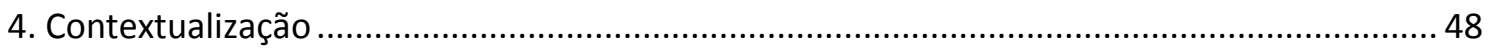

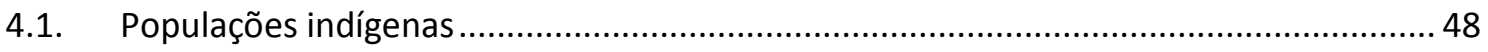

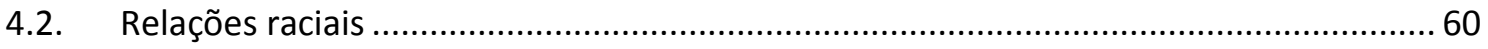

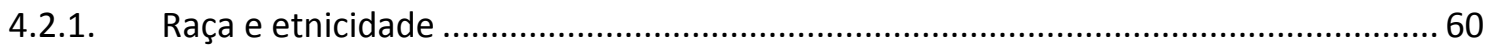

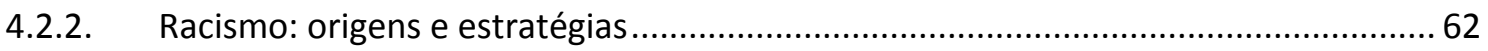


4.2.3. Contexto do racismo no Brasil e o preconceito contra indígenas 68

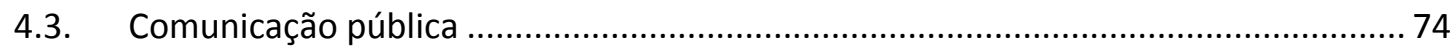

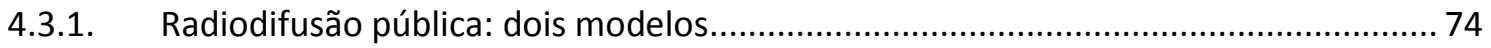

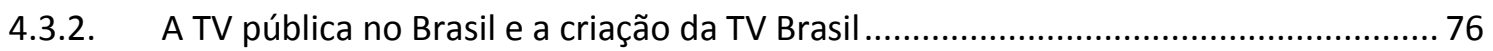

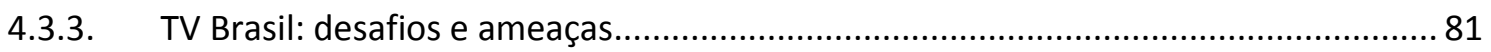

PARTE QUATRO - MOMBAK

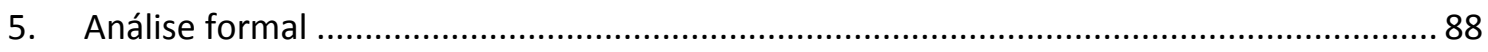

PARTE CINCO - TYBÁ

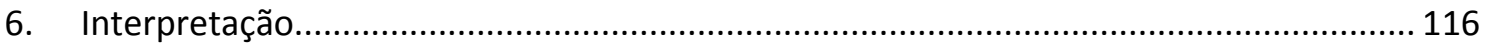

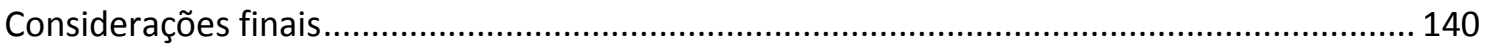

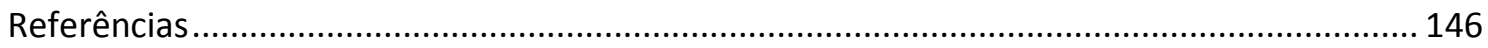




\section{Introdução}

As pessoas a quem nos referimos como "índios" descendem das populações que estavam no território antes da chegada do colonizador. Os portugueses não foram os primeiros forasteiros a atingirem o continente: muito antes das caravelas europeias, indícios arqueológicos apontam que povos da África, Austrália, Ásia e América Central teriam chegado ao território que convencionamos chamar América do Sul, convivendo e influenciando as populações que já viviam aqui (PROUS, 2007).

Após a chegada dos europeus, os habitantes do continente foram sujeitos às mais variadas violências. Seus territórios foram invadidos e tomados. Foram caçados, escravizados, estuprados, assassinados. Tiveram suas culturas, crenças, idiomas e conhecimentos perseguidos. Sofreram genocídios, pela pólvora e pela peste. Povos foram separados pela ponta da caneta, na divisão arbitrária do território. Resistiram - e resistem, a despeito das violências, da sociedade nacional, do Estado. Mas, passados 517 anos, ainda estão sob ameaça de desaparecimento e lutam diariamente pelo direito de existir (LUCIANO, 2006).

Na mídia dita comercial, o local das pessoas indígenas é o do silêncio ou do preconceito (REPRESENTANTES DE COLETIVOS INDÍGENAS DE PRODUÇÃO AUDIOVISUAL et al, 2013). Quando são retratadas, as populações indígenas aparecem de forma genérica e estereotipada. Sua representação oscila entre dois extremos: o bom selvagem, ingênuo e incapaz, necessitado da ajuda do Estado para todas as suas demandas; ou o vilão, selvagem, mentiroso, inimigo (LUCIANO, 2006). A mídia dita comercial não consegue compreender e retratar as populações indígenas dentro de suas complexidades, reproduzindo e reiterando preconceitos acerca dessas pessoas.

Um dos objetivos da radiodifusão pública é proporcionar um espaço contrahegemônico para a quebra de preconceitos, um canal onde as temáticas e vozes silenciadas e distorcidas na mídia dita comercial possam ser ouvidas (BUCCI et al, 2012). Neste sentido, como a TV Brasil, o principal veículo nacional de radiodifusão pública, está representando as populações indígenas?

O objeto deste trabalho é a representação das populações indígenas na TV Brasil, no período de 01/01/2008 a 31/12/2015, nas perspectivas da pluralidade e da diferença cultural. A pluralidade e a diferença cultural - conceituação atualizada da noção de "diversidade" - foram os conceitos escolhidos para guiar o nosso olhar, por representarem princípios sempre associados à boa prática da radiodifusão pública. 
Neste trabalho, usaremos o termo "indígena" para nos referir às pessoas que estavam no território hoje conhecido como Brasil quando da chegada do colonizador. Embora o movimento indígena organizado tenha se reapropriado e ressignificado o termo "índio", dando-lhe um sentido de união entre os povos que estavam aqui à chegada dos portugueses (LUCIANO, 2006), evitaremos utilizá-lo, por ainda poder carregar sentido pejorativo (CAVALCANTI, 2002). De acordo com documento produzido pela OnG Survive (online), movimento mundial pelos direitos dos povos indígenas, o termo "nativo" também carrega associações coloniais negativas, principalmente quando associado aos povos da América do Norte. Quando desejarmos nos referir às pessoas indígenas do ponto de vista geográfico, poderemos utilizar "ameríndio", termo utilizado para designar as pessoas do continente americano (SURVIVE, online).

Utilizaremos "populações indígenas" e "populações originárias" para nos referir ao conjunto dos povos que habitavam o território antes da chegada de outras populações, como europeus ou africanos. Survive explica que o conceito de povo diz respeito à "uma sociedade identificável distinta" (online). Assim, temos o povo Guarani Kaiowá, o povo Terena, o povo Tupinambá - e não a tribo Guarani Kaiowá, por exemplo. Tribo não diz respeito a uma etnia, mas à organização social que alguns povos adotam, ao redor de parentescos e alianças, que dá origem à sua organização política (LUCIANO, 2006). Tribo também não se refere ao local onde determinado povo reside - esta é a aldeia, a junção entre o território físico e a organização política de um conjunto de pessoas, que podem pertencer ao mesmo povo ou a povos diferentes (LUCIANO, 2006).

Para grafar os nomes dos diferentes povos indígenas, utilizaremos as regras estabelecidas pela Associação Brasileira de Antropologia - ABA (RICARDO, 2001). A maioria das linguagens indígenas têm fonemas que não estão presentes no português. Além disso, muitos povos residem separados entre dois ou três estados-nações, o que traz a necessidade de internacionalização da escrita de seus nomes, com letras que possam ser lidas da mesma forma em diferentes partes do mundo (RICARDO, 2001). Outra regra que adotaremos é a grafia dos nomes de cada povo em maiúscula e sem o plural - já que, nas diferentes línguas indígenas, o plural pode não existir, ou tem outro significado (RICARDO, 2001). Com a função de adjetivo, o nome de um povo será grafado em minúscula (RICARDO, 2001). Assim, ao contrário do que propõem manuais de redação de jornais como a Folha de São Paulo e o Estado de São Paulo - 
que indicam que os nomes devem ser aportuguesados, grafados em minúscula e flexionados de acordo com o número -, utilizaremos, por exemplo, "crianças Krahô", e não "crianças craôs" (RICARDO, 2001).

Cada momento deste trabalho está dividido em partes, que nomeamos com uma palavra em tupi antigo, a língua dominante quando da chegada dos portugueses (JECUPÉ, 1998). A primeira parte, que denominamos Moendy - em tupi antigo, “iluminar", “acender” (UNIVERSIDADE DE SÃO PAULO, online) -, será o começo de nossa caminhada. No capítulo um apresentaremos a justificativa para o trabalho, o problema de pesquisa e os objetivos geral e específicos.

No capítulo dois faremos um panorama da presença e da representação das pessoas indígenas na mídia audiovisual. O objetivo deste capítulo é compreender as formas como, historicamente, as populações indígenas que habitam o país vem sendo retratadas, como suas imagens são apresentadas e em quais contextos. Decidimos por incluir, no panorama, toda a produção audiovisual envolvendo indígenas, e não apenas a televisão - foco de nossa pesquisa -, pois a relação das populações indígenas com a TV não começou neutra e intocada no momento da primeira transmissão de uma pessoa indígena. Esta relação começa nos primórdios do cinema, com os filmes documentais de exploração, e atravessa as produções para a grande tela, na estética, temáticas e formas como as pessoas indígenas são representadas.

A segunda parte do trabalho, intitulada Xe r-apé - em tupi antigo, "meu caminho" (UNIVERSIDADE DE SÃO PAULO, online) -, compreenderá apontamentos acerca dos procedimentos metodológicos e dos principais conceitos que darão sustentação teórica ao trabalho. Importante frisar que a teoria também permeia o texto, dispersa da introdução à interpretação.

Iniciaremos o capítulo três com a apresentação do método de abordagem, a hermenêutica de profundidade (THOMPSON, 1995), explanando como se dará a pesquisa que nos propomos a realizar. O capítulo segue apresentando os conceitos de pluralidade e diferença cultural. Faremos um resgate conceitual de pluralidade em Norberto Bobbio (1995) e nos documentos da UNESCO sobre radiodifusão, e da diferença cultural em Homi K. Bhabha (2012) e nos documentos supracitados, para chegarmos ao nosso próprio entendimento de pluralidade e diferença cultural na radiodifusão pública. A partir destes conceitos, construiremos indicadores de pluralidade e de diferença cultural, que irão definir as categorias de análise e guiar nosso olhar durante a pesquisa. 
A terceira parte, intitulada $S$-apô - que significa "raiz" (UNIVERSIDADE DE SÃO PAULO, online) -, será a contextualização sócio-histórica das populações indígenas, das relações raciais no Brasil e da radiodifusão pública no país, com enfoque na TV Brasil. A contextualização se faz necessária, pois os assuntos que pesquisamos não se encontram suspensos no vácuo, independentemente dos acontecimentos sociais e políticos do passado e presente (THOMPSON, 1995). Para termos uma visão complexa de nossos objetos de pesquisa precisamos compreendê-los dentro da lógica em que estão inseridos.

Na quarta parte, Mombak - "fazer acordar" (UNIVERSIDADE DE SÃO PAULO, online) - realizaremos a análise descritiva dos resultados encontrados na pesquisa quantitativa. Como melhor abordaremos no capítulo dedicado aos apontamentos metodológicos, na pesquisa quantitativa identificaremos os conteúdos com temáticas relacionadas a indígenas na página da TV Brasil, por meio das palavraschave "índio", "indígena", "populações indígenas" e "cultura indígena". Uma vez definidos os conteúdos, assistiremos às programações integralmente, preenchendo fichas de análise com as categorias estabelecidas a partir dos conceitos de pluralidade e diferença cultural na radiodifusão pública.

Na quinta parte, Tybá - que significa "ajuntamento" (UNIVERSIDADE DE SÃO PAULO, online) -, juntaremos todos os vestígios para buscar uma compreensão possível das representações das populações indígenas na TV Brasil. No capítulo seis, realizaremos a interpretação dos dados encontrados na pesquisa quantitativa. Como explanaremos de forma mais aprofundada no capítulo dedicado aos apontamentos metodológicos, utilizaremos o recurso da nuvem de palavras para interpretar as categorias da pesquisa quantitativa e construir uma narrativa sobre as representações das populações indígenas, apontando limites e possibilidades para representações plurais e positivas do ponto de vista da diferença cultural. Por fim, teceremos as considerações finais, realizando apontamentos sobre as compreensões que obtivemos ao longo da pesquisa e sugestões para tornar a programação da TV Brasil mais plural e capaz de abarcar a diferença cultural, principalmente no concernente às populações indígenas. 
PARTE UM - MOENDY $Y^{1}$

\section{Justificativa, problema de pesquisa e objetivos}

De acordo com Alejandra Pinto (2011), pesquisadora em Representação da Informação, desde o primeiro contato com o colonizador as populações indígenas brasileiras recebem tratamento marcado pela objetificação nos meios de comunicação, o que é demonstrado pelas cartas de Pero Vaz de Caminha. Intelectuais indígenas argumentam que estas imagens "têm causado impacto sobre o tratamento colonial e legislativo dos indígenas" (PINTO, 2011, p. 56).

Joel Zito Araújo (2010) afirma que, na televisão dita comercial, existe uma super-representação de brancos e loiros e sub-representação de afrodescendentes e índio-descendentes. Para o autor,

É preciso que se faça, no Brasil, uma reflexão séria sobre essa disparidade entre a vida real e o que aparece na TV, e suas profundas consequências no processo de autoestima dos segmentos afro e índio-descendentes da população. (ARAÚJO, 2010, p 7)

Déborah Minardi (2012), especialista em Comunicação, argumenta que a representação social dos indígenas propagada pela mídia é massificadora e ancorada em noções que remetem ao colonialismo. De acordo com a autora, a mídia retrata o "índio" como um único povo genérico, esvaziando do conceito a multiplicidade de culturas e modos de vida presentes nas populações indígenas brasileiras, ao mesmo tempo em que o apresenta como diferente, marginalizado, preguiçoso (MINARDI, 2012).

Já a socióloga Patrícia Bandeira de Melo (2003), editora-chefe da revista Cadernos de Estudos Sociais da Fundação Joaquim Nabuco, aponta que a maior temática tratada pela mídia impressa com relação às populações indígenas gira em torno da violência. Para a autora, no discurso jornalístico os indígenas ocupam a posição de fonte passiva, com outras fontes ditas "oficiais" falando por estes grupos, o que gera silenciamento. De acordo com a autora,

Não há espaço para as diferenças culturais entre os vários grupos, as dificuldades de sobrevivência econômica, as questões internas de cada comunidade, as relações com o branco, os direitos e a ligação cultural à terra. Ou o índio ingressa na pauta jornalística dentro do tema violência ou fica no silêncio. (BANDEIRA DE MELO, 2003, p. 154)

1 "Iluminar", “acender” (UNIVERSIDADE DE SÃO PAULO, online).

2 “Meu caminho" (UNIVERSIDADE DE SÃO PAULO, online) 
A TV pública pode ser um meio adequado para a promoção da cidadania das populações indígenas. É necessário não apenas quebrar a estereotipização, mas também dar voz a essas pessoas. Abrir espaço nos meios de comunicação para que essas populações consumam e produzam seus próprios produtos comunicacionais é essencial à democratização dos meios de comunicação no país.

Proporcionar espaços para a pluralidade e para a formação crítica de cidadãos é parte da razão de ser das televisões públicas (BUCCI et al, 2012). No artigo "É possível fazer televisão pública no Brasil?", Eugênio Bucci (2010) enumera cinco bandeiras estéticas que a televisão pública deve observar. Dentre elas, estão "buscar o conteúdo que não cabe na TV comercial" e "emancipar em lugar de vender" - ambas alinhadas à necessidade de espaços na mídia pública que integrem as populações indígenas. Beth Carmona, no artigo "A Marca da TV Pública" (2006), apresentado no I Fórum de TVs Públicas, defende:

Hoje, não basta diferenciar a TV pública pela difusão de conteúdo nacional, pois outros já se apoderaram dessas marcas. Hoje, a Rede Pública que faz sentido se dará pela possibilidade de diversificar as opiniões, de abrir os conteúdos, de tratar de todos os temas e abordar todas as localidades. Essa será sua marca e sua qualidade. (CARMONA, 2006, p. 25)

No documento "Indicadores de qualidade nas televisões públicas - uma avaliação contemporânea" (BUCCI et al, 2012), os autores defendem que a televisão pública deve ser pautada por princípios, políticas e valores que priorizem a pluralidade de vozes, a experimentação da linguagem, a formação crítica e a quebra de estética de mercado (2012).

A preocupação em fazer das TVs públicas um espaço para pluralidade também se demonstra presente na legislação brasileira. A Constituição Federal, em seu artigo 231, reconhece às populações indígenas "sua organização social, costumes, línguas, crenças e tradições" (BRASIL, 1988). Já a "Declaração Universal dos Direitos dos Povos Indígenas”, da Organização das Nações Unidas - ONU -, assinada pelo Brasil em 2008, apregoa que:

11 Os povos indígenas têm o direito à dignidade e à diversidade de suas culturas, histórias, tradições e aspirações refletidas em todas as formas de educação e informação públicas. Os Estados tomarão medidas efetivas para eliminar os preconceitos e fomentar a tolerância, entendimento e boas relações. 
12 Os povos indígenas têm o direito ao uso e acesso a todas as formas de meios massivos de comunicação em suas próprias línguas. Os Estados tomarão medidas efetivas para alcançar este fim. (ONU, 2008)

A Lei $\mathrm{n}^{\circ}$ 13.018, conhecida como Lei Cultura Viva (BRASIL, 2014), transformou o Programa Nacional de Promoção da Cidadania e da Diversidade Cultural - Cultura Viva - em uma política pública. Seu principal objetivo é ampliar o acesso da população brasileira aos seus direitos culturais, mediante fortalecimento de grupos culturais já atuantes na comunidade. De acordo com o artigo $2^{\circ}$ da lei, outros objetivos são:

I - garantir o pleno exercício dos direitos culturais aos cidadãos brasileiros, dispondo-lhes os meios e insumos necessários para produzir, registrar, gerir e difundir iniciativas culturais; [...]

$\mathrm{V}$ - garantir o respeito à cultura como direito de cidadania e à diversidade cultural como expressão simbólica e como atividade econômica; [...]

VII - promover o acesso aos meios de fruição, produção e difusão cultural. (BRASIL, 2014)

De acordo com o artigo 221 da Constituição Federal (BRASIL, 1988), incisos I a III, os princípios que devem guiar a produção e a programação das emissoras de rádio e televisão incluem os de preferência a finalidades educativas, artísticas, culturais e informativas, promoção da cultura nacional e regional, estímulo à produção independente e regionalização da produção cultural, artística e jornalística. O artigo 223 da Constituição Federal (BRASIL, 1988) exige a complementariedade dos sistemas público, privado e estatal. Portanto, se a TV dita comercial não apresenta uma representação plural de populações indígenas, ao menos a pública deve fazê-lo.

Já o artigo 215, parágrafo $1^{\circ}$ (BRASIL, 1988) apregoa que o Estado protegerá as manifestações das culturas populares, indígenas e afro-brasileiras. $\mathrm{O}$ parágrafo $3^{\circ}$ desse mesmo artigo legisla sobre o Plano Nacional de Cultura, ao qual a Emenda Constitucional $n^{\circ} 48$ de 2005 acrescentou os incisos de I a IV. Tais incisos determinam que as ações do Plano Nacional de Cultura devem conduzir à democratização do acesso aos bens de cultura e valorização da diversidade étnica e regional (BRASIL, 2005).

O dispositivo de criação da Empresa Brasileira de Comunicação - EBC -, a Lei $\mathrm{n}^{\mathrm{o}} 11.652$, de 7 de abril de 2008 , em seu artigo $2^{\circ}$, define os princípios que devem reger a prestação dos serviços de radiodifusão pública. Dentre estes princípios, estão os expostos nos incisos II, IV, VI e IX, que pregam, respectivamente, "promoção do acesso à informação por meio da pluralidade de fontes de produção e distribuição do 
conteúdo", "promoção da cultura nacional, estímulo à produção regional e à produção independente", "não discriminação religiosa, político partidária, filosófica, étnica, de gênero ou de opção sexual" e "participação da sociedade civil no controle da aplicação dos princípios do sistema público de radiodifusão, respeitando-se a pluralidade da sociedade brasileira" (BRASIL, 2008). Em seu artigo 3º, a Lei n 11.652 (Brasil, 2008) define os objetivos dos serviços de radiodifusão pública. Dentre estes, destacamos:

I - oferecer mecanismos para debate público acerca de temas de relevância nacional e internacional;

II - desenvolver a consciência crítica do cidadão, mediante programação educativa, artística, cultural, informativa, científica e promotora de cidadania;

III - fomentar a construção da cidadania, a consolidação da democracia e a participação na sociedade, garantindo o direito à informação, à livre expressão do pensamento, à criação e à comunicação;

IV - cooperar com os processos educacionais e de formação do cidadão;

V - apoiar processos de inclusão social e socialização da produção de conhecimento garantindo espaços para exibição de produções regionais e independentes. (BRASIL, 2008)

Emissoras públicas já são utilizadas como meio de promoção da cidadania de populações indígenas, tanto na América Latina, quanto em outras partes do mundo. $\mathrm{Na}$ Bolívia existe um programa semanal de TV em língua quíchua, voltado para as comunidades indígenas, e no México existe a TV Oaxaca, com programação produzida pelas comunidades indígenas do Sul (COUTO; PAVAN, 2010). No Canadá, em 1981 surgiu a Inuit Broadcasting Corporation, culminando com a estreia da Aboriginal Peoples Television Network - APTN, em 1999 (ROTH, 2005). Na Nova Zelândia, a TV Maori, produzida e protagonizada pelos Maori, funciona desde 2004 (TV MAORI, 2014). Na Argentina, a Lei de Meios Audiovisuais, sancionada em 2009, realizou concessões de radiodifusão para várias nações originárias, e em 2013 a primeira emissora argentina comandada por pessoas indígenas, a Wall Kintun, entrou no ar (PERES, 2013). Na Austrália, a Walpiri Media Association - WMA foi criada em 1983 e tem trabalhado com a SBS, o braço cultural da emissora pública australiana ABC, em diversas colaborações de sucesso (GINSBURG in GISNBURG et al, 2002). Desde 2007, a SBS mantém um canal indígena, a National Indigenous Television - NTIT (NTIT, 2014).

No Brasil, o único programa dedicado exclusivamente às populações indígenas, o “A’Uwe”, realizado pela TV Cultura de São Paulo por meio de parcerias 
entre indígenas e não-indígenas, foi cancelado em 2010, após dois anos e meio de exibição (MILAN, 2013). De acordo com a diretora da série, a jornalista e cineasta Laine Milan, em entrevista ao programa Ver TV exibido em 08/11/2013, “A’Uwe” foi composto de 79 episódios, exibindo no total 120 documentários (MILAN, 2013). Milan (2013) afirma que o programa foi cancelado após uma mudança de gestão na presidência da Fundação Padre Anchieta.

Um estudo realizado em 2010 pela Fundação Cultural Palmares, por ocasião do II Fórum Nacional de TVs Públicas, lança alguma luz à questão da presença de indígenas na TV pública. Segundo a pesquisa, que investigou a programação da TV Brasil, TV Cultura e TV Nacional, “a programação atual das TVs Públicas expressa um baixo perfil de reflexão sobre o pluralismo cultural brasileiro" (ARAÚJO, 2010, p. 5). No entanto, o estudo, embora envolva a presença das populações indígenas na TV pública, tem como foco a representação de pessoas negras. A presença indígena fica, por vezes, silenciada e relegada a segundo plano no trabalho.

Outro estudo que enfoca a representação de indígenas na TV pública é o artigo “Gênero, cultura e hibridização no programa A’Uwe da TV Cultura”, de Marcelo do Nascimento Melchior (2011), mestre em Comunicação pela Universidade Federal do Goiás. Afora estes estudos, não encontramos nenhum outro que investigue a presença das populações indígenas na televisão pública brasileira. Realizamos a busca na ferramenta Google e no banco de teses e dissertações da BCE/UnB, IBICT e Capes, por meio de combinações entre as palavras-chave "indígena", "índio", "mídia", "comunicação", "comunicação pública" e "televisão". A maior parte dos resultados relacionava-se à Antropologia e Linguística. Dentro da Comunicação, a ênfase dos estudos recaiu sobre a representação de indígenas na mídia dita comercial e no papel das novas tecnologias como vetores de comunicação alternativa - em sua maioria, estudos de caso sobre povos que usam blogs, web rádios, dentre outros, para preservar suas culturas, entrar em contato com outros povos e disseminar conhecimento.

Assim, se faz necessário um estudo que busque compreender as maneiras como as populações indígenas são representadas na TV pública brasileira - em especial, na TV Brasil, carro-chefe do aparelho de radiodifusão pública nacional -, a fím de contribuir para um melhor entendimento da TV pública no país e proporcionar ferramentas para a construção de uma mídia pública mais cidadã e alinhada aos princípios da pluralidade, livre informação e acesso à cultura (BUCCI et al, 2012). Do ponto de vista acadêmico, o estudo se justifica pela ausência de outros estudos mais 
aprofundados que foquem a presença indígena na televisão pública brasileira. Do ponto de vista social, o estudo lança luz a populações que sofreram genocídios, tiveram suas culturas perseguidas, seus conhecimentos relegados a inferiores e que, ainda hoje, correm o risco de desaparecerem (LUCIANO, 2006), investigando o papel da TV Brasil como canal de respeito à diferença e veículo de pluralidade. Desejamos compreender se a TV Brasil consegue contemplar a diferença e a pluralidade das populações indígenas em sua programação - e, em caso contrário, apontar as maneiras como está falhando.

Neste contexto, coloca-se o problema de pesquisa: quais as representações das populações indígenas na TV Brasil, no período de 2008 a 2015? Delimitamos o período temporal para abranger os anos em que a programação da TV Brasil estava protegida por mecanismos como o Conselho Curador.

Nosso objetivo geral é resgatar e analisar as representações das populações indígenas na TV Brasil, apontando limites e possibilidades para contemplar diferença e pluralidade. Como objetivos específicos, pretendemos conceituar pluralidade e diferença na radiodifusão pública; discutir as missões da radiodifusão pública no que tange à sua programação no tratamento da temática dos povos indígenas; apontar diferenças e semelhanças no período analisado; estabelecer a frequência das representações de pessoas indígenas e apontar onde se concentram; destacar o local dos indígenas na programação da EBC; compreender a quem se destinam os conteúdos relacionados às temáticas indígenas; apontar por quem são produzidos tais conteúdos e quais temáticas abordam; estabelecer se as representações das populações indígenas mudaram com o passar dos anos; e sugerir mudanças na atual programação e nas ações empreendidas pela TV Brasil. Os objetivos são melhores explanados pelo quadro a seguir.

Quadro 1 - Objetivos de Pesquisa

\begin{tabular}{|l|l|l|}
\hline 1 & $\begin{array}{l}\text { A minha pesquisa se } \\
\text { propõe a... }\end{array}$ & investigar as representações das populações indígenas na TV Brasil. \\
\hline 2 & Para... & $\begin{array}{l}\text { delimitar as representações das populações indígenas, a frequência } \\
\text { da presença indígena e os gêneros televisivos, bem como o período } \\
\text { em que estão inseridos na grade de programação. }\end{array}$ \\
\hline $\mathbf{3}$ & Com a finalidade de... & $\begin{array}{l}\text { identificar os limites e possibilidades para contemplar diferença e } \\
\text { pluralidade na programação e estabelecer se a programação da TV } \\
\text { Brasil está de acordo com princípios que orientam a televisão } \\
\text { pública, expressos na literatura. }\end{array}$ \\
\hline $\mathbf{4}$ & O que irá permitir... & $\begin{array}{l}\text { a sugestão de mudanças na atual programação e nas ações } \\
\text { empreendidas pela TV Brasil, uma melhor compreensão da televisão } \\
\text { pública no Brasil e a construção de uma mídia pública mais cidadã. }\end{array}$ \\
\hline
\end{tabular}

Fonte: Elaboração própria. 
Neste capítulo, justificamos a escolha da temática, apresentamos o problema de pesquisa e os objetivos geral e específicos. No próximo, faremos um panorama da presença e representações indígenas nas mídias audiovisuais no Brasil, para compreender o ponto de partida e contextualizar a relação entre a mídia dita comercial e as populações indígenas. 
PARTE DOIS - XE R-APÉ ${ }^{2}$

\section{Apontamentos teórico-metodológicos}

\subsection{Procedimentos metodológicos}

O método de abordagem que adotamos é a hermenêutica de profundidade (HP). A HP admite na pesquisa as influências do pesquisador, em vez de negá-las, na intenção de neutralizá-las (VERONESE; GUARESCHI, 2006). Admite, também, uma dupla ruptura epistemológica, que reconcilia a pesquisa com o senso comum, aproximando-o de um "senso comum emancipado" (VERONESE; GUARESCHI, 2006, p. 86). Acreditamos que, na aproximação dos processos de sentidos relacionados a populações que historicamente tiveram suas culturas tratadas como primitivas pela ciência moderna, a dupla ruptura demonstra-se uma escolha metodológica honesta. Além disso, essa ferramenta teórico-metodológica não se propõe a encontrar verdades definitivas, ou mesmo desvelar tudo o que há para se saber sobre um objeto, apenas propõe sentidos possíveis (VERONESE; GUARESCHI, 2006). Essa perspectiva fornece segurança para lidar com um objeto tão pulsante e rico.

O sociólogo John Thompson, em sua obra "Ideologia e cultura moderna: teoria social crítica na era dos meios de comunicação de massa" (1995), sugere a HP como ferramenta teórico-metodológica para estudos que pretendam analisar objetos que envolvam ideologia, cultura e comunicação de massa. O autor frisa que os estudos de formas simbólicas são, essencialmente, atividades de compreensão e interpretação, e que, devido à tradição positivista, existe uma "tentação constante de tratar fenômenos sociais em geral, e formas simbólicas em particular, como se elas fossem objetos naturais, passíveis de vários tipos de análise formal, estatística e objetiva" (THOMPSON, 1995, p. 357-358). Thompson (1995) não deseja, com isso, descartar tais modalidades de análise, mas sugerir que constituem um enfoque parcial dos estudos sociais e de formas simbólicas. Por isso, sugere fases que a pesquisa deve seguir para, em suas palavras, "evitar os perigos que caracterizam a maioria dos trabalhos anteriores sobre o caráter ideológico da comunicação de massa" (THOMPSON, 1995, p. 357). Tais fases têm como cerne a interpretação e, ao invés de isolar o objeto, pretendem posicioná-lo em um contexto histórico-social onde, antes de tudo, é sujeito, interpretado

\footnotetext{
2 “Meu caminho" (UNIVERSIDADE DE SÃO PAULO, online)
} 
e reinterpretado, que possui voz e é capaz de influir em sua própria trajetória (THOMPSON, 1995). De acordo com Thompson (1995),

$\mathrm{Na}$ investigação social o objeto de nossas investigações é, ele mesmo, um território pré-interpretado. O mundo sócio-histórico não é apenas um campo-objeto que está ali para ser observado; ele é também um campo-sujeito que é construído, em parte, por sujeitos que, no curso rotineiro de suas vidas quotidianas, estão constantemente preocupados em compreender a si mesmos e aos outros, e em interpretar as ações, falas e acontecimentos que se dão ao seu redor. (THOMPSON, 1995, p. 358)

Assim, pretendemos seguir as quatro fases da HP sugeridas por Thompson (1995). É importante frisar que essas não são fases distintas e sequenciais, mas partes do mesmo processo hermenêutico complexo, e podem aparecer combinadas durante o trabalho.

A primeira fase proposta por Thompson (1995) não é bem uma fase, mas uma pré-análise, "um estágio preliminar indispensável ao enfoque da HP” (THOMPSON, 1995, p. 363). Esta fase é a interpretação da doxa, que são os sentidos pré-interpretados pelos sujeitos que constituem o campo sujeito-objeto (THOMPSON, 1995). Visa investigar como as pessoas que produzem, reproduzem e são afetadas pelas formas simbólicas compreendem-nas e interpretam-nas (THOMPSON, 1995). Assim, traremos, ao longo do trabalho, a percepção de indígenas e não-indígenas sobre a relação dos povos originários com a mídia e os estereótipos e preconceitos que recaem sobre tais grupos no Brasil. Também realizamos, no capítulo anterior, um panorama das compreensões da presença e representação indígena nas mídias audiovisuais, uma síntese da ideologia reforçada pela mídia dita comercial acerca das populações indígenas.

A segunda fase é a análise sócio-histórica, a contextualização social e histórica do objeto-sujeito (THOMPSON, 1995). Segundo explana o autor, os sujeitos estão sempre inseridos no tempo: as pessoas são parte da história, e não apenas espectadoras desta (THOMPSON, 1995). Segundo Thompson (1995), o processo de interpretação nunca deve ser feito de forma isolada de seu contexto:

A experiência humana é sempre histórica, no sentido de que uma nova experiência é sempre assimilada aos resíduos do que passou, e no sentido que, ao procurar compreender o que é novo, nós sempre e necessariamente construímos sobre o que está presente. (THOMPSON, 1996, p. 360) 
No caso das populações indígenas, a análise sócio-histórica demonstra-se duplamente necessária, uma vez que o contexto histórico está intimamente ligado ao preconceito que essas populações sofrem e ao tratamento que a mídia lhes confere. De acordo com Peter Wade (2000), antropólogo britânico especializado em raça e etnicidade na América Latina, "hay diferentes racismos, pero en mi opinión, se vinculan de formas históricamente diversas a la historia de los enfrentamientos coloniales" (p. 29).

Assim, é necessário fazer um levantamento histórico, não apenas da trajetória das populações indígenas desde a chegada do colonizador, mas também das relações raciais no Brasil. Para a contextualização histórica da trajetória dos povos originários, privilegiaremos o olhar dos povos indígenas, selecionando autores que pertencem a povos originários. Importante frisar que outros trabalhos já realizaram com muita propriedade e credibilidade o resgate da história das pessoas indígenas, por isso, não é nosso objetivo esgotar esse tópico, mas apresentar outra visão e realizar uma contextualização que se dará concomitantemente ao desenvolvimento conceitual.

Realizaremos, também, um resgate da história da TV pública no Brasil, contextualizando o atual momento da radiodifusão pública brasileira. De acordo com Thompson, "o objetivo da análise sócio-histórica é reconstruir as condições sociais e históricas de produção, circulação e recepção das formas simbólicas” (THOMPSON, 1995, p. 366).

O terceiro momento proposto por Thompson é o da análise formal, que compreende a investigação do objeto em sua forma estruturada, em sua mensagem e em seus objetivos (THOMPSON, 1995). Thompson (1995) afirma que, para além de estarem inseridos em um contexto histórico, os objetos também são "construções simbólicas complexas que apresentam uma estrutura articulada" (THOMPSON 1995, p. 369). Esta estrutura deve ser analisada utilizando métodos de análise formais (THOMPSON, 1995).

Nessa fase realizaremos a análise descritiva quantitativa dos conteúdos da TV Brasil, cujas temáticas abarquem pessoas indígenas, desde a estreia da emissora, em 2008, até 2015. Acreditamos que não seja suficiente analisar apenas um programa ou quadro - até porque atualmente não existe uma programação voltada especificamente para o público indígena. A forma como a TV Brasil representa essas populações está

\footnotetext{
3 "Existem diferentes formas de racismo, mas, em minha opinião, se vinculam de formas historicamente diversas à história dos enfrentamentos coloniais" (Tradução nossa)
} 
dispersa pela grade de programação, e é preciso recuperar esses vestígios para compreender a imagem que a emissora constrói acerca das populações nativas. A pesquisa dos conteúdos será feita a partir da ferramenta de busca na página da emissora, por meio das palavras-chave "índio", “indígena”, "cultura indígena” e "populações indígenas".

Os conteúdos serão assistidos integralmente e catalogados em fichas de análise. O nosso olhar - e, consequentemente, as categorias de análise -, será guiado pelos conceitos de pluralidade e diferença na radiodifusão pública, que trabalharemos no próximo tópico. As categorias de análise também serão explanadas detalhadamente nos próximos tópicos.

Descreveremos cada categoria de acordo com sua frequência, a fim de montar um mapa da presença e representações indígenas na TV Brasil. As categorias de análise também serão cruzadas entre si, com os resultados explanados em gráficos. Desejamos saber, com a análise quantitativa, por exemplo, se a frequência e intensidade da programação aumentam com a proximidade do Dia do Índio, ou qual a relação entre os conteúdos para índios e sobre índios - e, ainda, quantos são realizados por índios.

$\mathrm{Na}$ próxima fase, a interpretação, a pesquisa quantitativa encontrará a qualitativa. Os termos mais recorrentes na pesquisa quantitativa irão compor uma "nuvem de palavras", um recurso para visualização dos vocábulos - compreendidos aqui como porções de significado (ORLANDI, 2005) - relacionados às populações indígenas. Thompson (1995) explica que a interpretação é facilitada pelos métodos de análise formal, mas é distinta destes. Os métodos de análise formal "quebram, dividem, desconstroem, procuram desvelar os padrões e efeitos que constituem e que operam dentro de uma forma simbólica ou discursiva" (THOMPSON, 1995, p. 375). A interpretação procede sobre estes resultados, construindo uma síntese criativa de possíveis significados - carregando, portanto, a vivência e o olhar de quem interpreta (THOMPSON, 1995). Thompson (1995) explica que, como a interpretação se dá sobre objetos e campos previamente interpretados por sujeitos, este processo é simultaneamente o de reinterpretação. A interpretação/reinterpretação também ocorrerá em todas as fases do trabalho - problematizar um tema, realizar um recorte e desenvolvê-lo já implica em novas interpretações.

A nuvem de palavras é um recurso gráfico para visualização de palavras e temáticas presentes em textos verbais e não-verbais, de acordo com sua frequência. Em sua tese de doutoramento, intitulada "História da formação de professores de 
matemática do ensino primário em Minas Gerais: estudos a partir do acervo de Alda Lodi (1927 a 1950)", defendida na Universidade Federal de Minas Gerais, Diogo Alves de Faria Reis (2014) explica a ferramenta:

\begin{abstract}
Uma nuvem de palavras é uma representação gráfica da frequência de palavras encontradas em um texto. Nessa representação, o tamanho de fonte de cada palavra dentro da nuvem varia de acordo com o número de vezes em que ela aparece ao longo do texto. À medida que a quantidade de palavras no texto aumenta, aumenta, também, o tamanho da fonte usada em sua escrita na "nuvem", mantendo-se uma proporção entre a frequência da palavra e o tamanho da fonte utilizada em sua representação. (REIS, 2014, p. 194)
\end{abstract}

Assim, a nuvem de palavras juntará os elementos imagéticos - transformados em palavras - e textuais das programações, cruzando e expandindo as categorias. A partir desta nuvem de palavras, construiremos uma narrativa explicando de que modo as temáticas aparecem, relacionando as fontes, os gêneros televisivos e as demais categorias e abordando quanto e como as pessoas indígenas são representadas na TV Brasil. A partir das categorias, vamos "subir" aos indicadores de pluralidade e diferença cultural, para tecer compreensões possíveis sobre como a TV Brasil pode contemplar pluralidade e diferença cultural.

No próximo tópico, iremos explorar os conceitos de pluralidade e diferença cultural na radiodifusão pública, desenvolvendo indicadores que irão guiar a análise formal e a interpretação/reinterpretação.

\title{
3.2. Pluralidade e diferença cultural
}

"Pluralidade" e "diversidade" são conceitos essenciais quando se fala em radiodifusão pública. Os termos permeiam os discursos, a literatura da área e a letra da lei, relacionados aos princípios e finalidades das emissoras públicas de radiodifusão. No entanto, poucos se preocupam em definir conceitualmente "pluralidade" e "diversidade", e os conceitos são, muitas vezes, intercambiados, utilizados como sinônimos. Neste trabalho, retomaremos as conceituações de pluralidade e diversidade propondo atualizá-la para a noção de "diferença". Também identificaremos os conceitos na literatura da UNESCO, para compor o nosso próprio entendimento de pluralidade e diferença na radiodifusão pública. 
O filósofo italiano Norberto Bobbio dedica a primeira parte de sua obra "As ideologias e o poder em crise" (1995) à discussão da pluralidade. O autor define o pluralismo como "a valorização dos grupos sociais que integram o indivíduo e desintegram o Estado" (BOBBIO, 1995, p. 20). Bobbio (1995) afirma que a ideia de que uma sociedade é tanto melhor quanto mais repartido estiver o poder é antiga e se encontra em toda a história do pensamento político. Em Maquiavel, este critério era a distinção entre o reino turco e o francês - onde a monarquia francesa seria preferível, pois o monarca estaria cercado de outros nobres, eles mesmos reconhecidos e amados pelo povo (BOBBIO, 1995). Na análise de Montesquieu sobre governos despóticos, a distinção entre estes e os não-despóticos seria a ausência nos primeiros de "corpos intermediários" (BOBBIO, 1995, p. 15). Hegel defendia que a pluralidade surgida nas “esferas particulares” (BOBBIO, 1995, p. 16) que se desenvolvem no corpo social é a única garantia contra o absolutismo do monarca.

Bobbio (1995) não descarta essas noções, e acrescenta que nossas sociedades são organismos complexos, onde se formaram "esferas particulares relativamente autônomas" (BOBBIO, 1995, p. 16) - como partidos políticos, sindicatos, etc. -, dentre grupos organizados e grupos não organizados. Para o autor, a melhor forma de organizar sociedades complexas é "fazer com que o sistema político permita aos vários grupos ou camadas sociais que se expressem politicamente, participem, direta ou indiretamente, na formação da vontade coletiva" (BOBBIO, 1995, p. 16). Nessa perspectiva encontramos a própria noção de democracia, como expressão política da vontade coletiva. Nas palavras de Bobbio (1995):

Pluralismo evoca positivamente um estado de coisas onde não existe um poder monolítico e no qual, pelo contrário, havendo muitos centros de poder bem distribuídos territorial e funcionalmente, o indivíduo tem a máxima possibilidade de participar na formação das deliberações que lhe dizem respeito, o que é a quintessência da democracia. (BOBBIO, 1995, p. 22)

Vemos, também, que a pluralidade está relacionada à ação política. Bobbio (1995) afirma que o pluralismo reflete não apenas uma ideia antidespótica, mas também antiestatal. Com o avanço da pluralidade, o Estado passaria a ficar obsoleto - o próprio Estado um momento necessário, mas não final (BOBBIO, 1995). Para o autor, o pluralismo é contrário à ideia de Estado forte, unitário e mediador na guerra de todos contra todos (BOBBIO, 1995). 
Bobbio (1995) define as três correntes pluralistas, cada qual ligada a um sistema ideológico: socialismo, cristianismo social e liberalismo democrático. O socialismo que se autodefine pluralista é o socialismo sindicalista, que busca a democracia nos grupos menores, organizados e não organizados (BOBBIO, 1995). O pluralismo dentro do cristianismo social apregoa que a vida humana existe dentro de sociedades: o Estado - sociedade política -, família, associações profissionais e de outras naturezas, Igreja e sociedade internacional (BOBBIO, 1995). Já o pluralismo liberal-democrata defende que o poder parcial de um grupo deve ser controlado pelo poder parcial de outro - devem existir muitos centros de poder, nenhum deles mais soberano que o outro (BOBBIO, 1995).

As correntes pluralistas podem ser identificadas de acordo com dois critérios (BOBBIO, 1995). O primeiro critério é o pluralismo arcaizante e o pluralismo modernizante (BOBBIO, 1995). Bobbio (1995) defende que o pluralismo pode ser identificado com um olhar para o passado ou para o futuro. Para o passado, temos as comunidades artesãs, o núcleo familiar - o particularismo. Para o futuro, as organizações da sociedade civil, "que tende a absorver a sociedade política" (BOBBIO, 1995, p. 20). Bobbio (1995) estabelece o critério de diferenciação como uma concepção passiva e saudosa da história e um posicionamento que vê a história como "um processo em contínuo desenvolvimento mediante a inserção do novo no velho" (BOBBIO, 1995, p. 21).

O segundo critério apontado por Bobbio (1995) é a forma como cada pluralismo enxerga a sociedade: se como uma estrutura monolítica ou um multiverso. $\mathrm{O}$ autor chama a essa distinção de modelo orgânico e modelo mecânico (BOBBIO, 1995). Ambos partem da ideia de uma sociedade composta por vários grupos organizados e não organizados, mas a forma de articulação em cada modelo é diferente (BOBBIO, 1995). No modelo orgânico, os grupos estão dispostos de maneira hierarquizada e finalística, com cada parte colocada de acordo com sua função e papel, como em um organismo (BOBBIO, 1995). Neste modelo, a ordem social é preestabelecida (BOBBIO, 1995). No modelo mecânico, a relação entre os entes se dá com base no conflito existente entre eles, e o todo é "o resultado jamais definitivo de um equilíbrio de forças que se cindem e se recompõem continuamente" (BOBBIO, 1995, p. 21). Neste modelo, a ordem social é o resultado contínuo e mutável desse embate, que modifica e renova a realidade (BOBBIO, 1995). "O primeiro modelo é mais estático, o segundo, mais dinâmico" (BOBBIO, 1995, p. 22). 
A pluralidade na radiodifusão foi alvo do documento "Um Mundo, Muitas Vozes" (UNESCO, 1980), também conhecido como Relatório Macbride. No capítulo quatro, "Concentration",", há um tópico sobre "Pluralism in ownership and control" 5 ". Este capítulo dedica-se a realizar uma descrição de como se dá o controle e propriedade da radiodifusão nos diferentes continentes, sem realizar uma análise mais aprofundada das consequências de cada tipo de propriedade e o caráter das emissoras - públicas, estatais ou privadas (UNESCO, 1980).

Uma abordagem mais próxima do conceito de pluralidade explorado por Bobbio (1995) está em um dos principais apontamentos do relatório, sobre a concentração midiática e as desigualdades sociais e tecnológicas entre os países ditos desenvolvidos e subdesenvolvidos (UNESCO, 1980). O relatório apontou que os fluxos de informação se davam de maneira norte/sul e oeste/leste, evidenciando as diferenças sociais e ideológicas no mundo (UNESCO, 1980). O documento aponta que, dentre as principais causas para o desequilíbrio comunicacional nos países ditos subdesenvolvidos, estava a concentração do fluxo informacional em quatro agências: a Agence France Presse e a britânica Reuters; e a Associated Press e United Press International, estadunidenses (UNESCO, 1980).

No relatório da UNESCO “Radiodifusão pública: por quê? Como?” (2001a), a pluralidade da audiência aparece como um dos critérios para medir a performance da emissora pública. Nesse sentido, quanto mais plural a audiência, mais bem sucedida a emissora. Já no documento "Indicadores de qualidade nas emissoras públicas - uma avaliação contemporânea" (BUCCI et al, 2012), a pluralidade é apontada como característica fundamental da radiodifusão pública. $\mathrm{O}$ documento defende que a natureza das emissoras públicas está em garantir o direito da sociedade “à informação, à cultura, à expressão de suas diferenças, à tematização de suas carências e potencialidades e à livre comunicação das ideias" (BUCCI et al, 2012, p. 13) - valores associados à pluralidade. No caso das televisões públicas, o documento defende que esta deve ser pautada por princípios e políticas que priorizem a pluralidade de vozes (BUCCI et al, 2012).

Neste trabalho, no estabelecimento das categorias para a análise formal dos conteúdos da TV Brasil, procuraremos nos aproximar de uma noção de pluralidade que vê a história como um processo em constante desenvolvimento e que considera o tecido

\footnotetext{
4 “Concentração", tradução nossa.

5 "Pluralidade na propriedade e no controle", tradução nossa.
} 
social como o resultado dos diversos embates ali travados. Nosso critério de pluralidade na radiodifusão pública é a práxis, a contextualização histórica, a abordagem de temáticas que reflitam posicionamentos diversos - em oposição ao silenciamento, à negação do conflito, ao consenso forçado. Entendemos a pluralidade como um dos princípios norteadores da radiodifusão pública. Pluralidade em uma emissora pública significa não apenas dar voz a diferentes grupos, mas abrir maior espaço para que grupos que não possuem voz na mídia dita comercial pautem suas próprias demandas.

Já o conceito de diversidade, como aponta Eduardo Bolán (2013), professor do Departamento de Antropologia da Universidade Autônoma Metropolitana da Cidade do México, tem sofrido revisões nos últimos trinta anos. Desde o lançamento da reconhecida obra de Edward Said, "Orientalismo: o Oriente como invenção do Ocidente", discute-se o domínio do colonizador sobre a representação e a perspectiva epistemológica do colonizado (BOLÁN, 2013). Paralelamente, o questionamento da objetividade nas Ciências Sociais e o resgate de visões que privilegiam a subjetividade e a convivência de múltiplas narrativas abriram espaço para a discussão da diversidade e da diferença (BOLÁN, 2013).

A Declaração Universal sobre a Diversidade Cultural (UNESCO, 2001b) estabelece princípios para a preservação e valorização da diversidade cultural. $O$ documento compreende a cultura como:

\footnotetext{
O conjunto dos traços distintivos espirituais e materiais, intelectuais e afetivos que caracterizam uma sociedade ou um grupo social e que abrange, além das artes e das letras, os modos de vida, as maneiras de viver juntos, os sistemas de valores, as tradições e as crenças. (UNESCO, 2001b, preâmbulo)
}

Neste contexto, a diversidade cultural são as diferenças entre as características de cada um desses grupos. Na declaração, a UNESCO (2001b) afirma que o respeito à diversidade cultural, à tolerância, diálogo e cooperação são as maiores garantias de paz e segurança internacionais. A diversidade cultural é enxergada como existente dentro de sociedades e, portanto, sua expressão é sujeita às regras sociais dominantes (UNESCO, 2001b). O documento entende a diversidade cultural como "patrimônio comum da humanidade" (UNESCO, 2001b, art. $1^{\circ}$ ) e parte dos direitos humanos. As identidades que compõem as diversidades culturais são tidas como dinâmicas e plurais, porém a globalização é tomada como uma ameaça às diversidades - vistas como "puras", "intocadas" (UNESCO, 2001b). O documento afirma, entretanto, que as tecnologias de 
comunicação têm o potencial de aproximar o diálogo entre culturas (UNESCO, 2001b). A declaração afirma que a garantia de livre circulação de ideias é essencial à diversidade cultural, e que todas as culturas devem ter acesso aos meios de produção e distribuição de conteúdos (UNESCO, 2001b). O mercado não é suficiente para garantir essa inclusão - e, portanto, o documento defende a necessidade de políticas públicas para a diversidade cultural, não apenas no âmbito da Comunicação (UNESCO, 2001b).

O documento "Um Mundo, Muitas Vozes" (UNESCO, 1980), embora não trate especificamente de diversidade cultural, traz um tópico sobre culturas e sua interação com as tecnologias de comunicação. Na terceira parte do documento, "Problems and issues of common concern" ${ }^{6}$, no tópico “Cultural alienation"” (UNESCO, 1980, p. 159), o Relatório Macbride expressa preocupação com a proliferação das tecnologias de comunicação - em especial, a televisão -, e com seus efeitos devastadores nas culturas. De acordo com o relatório:

The introduction of new media, particularly television into traditional societies has seldom failed to shake centuries-old customs, time-honored cultural practices and simple life styles, social aspirations and economic patterns ${ }^{8}$. (UNESCO, 1980, p. 160)

No relatório da UNESCO “Radiodifusão pública: por quê? Como?” (2001a), a diversidade é apontada como um dos quatro princípios da radiodifusão pública. No entanto, o conceito é utilizado mais no sentido de diversificação da programação do que de diversidade cultural.

O serviço oferecido pela radiodifusão pública deve ser diversificado em pelo menos três maneiras: em termos de gêneros de programas oferecidos, público-alvo e temas discutidos. Radiodifusão pública deve refletir a diversidade de interesses públicos, oferecendo diferentes tipos de programas, a partir de noticiários para programas leves. Alguns programas podem ser destinados à única parte do público, cujas expectativas são variadas. No final, a radiodifusão pública deve atingir a todos, não através de cada programa, mas através de todos os programas e sua diversidade. Finalmente, através da diversidade dos assuntos discutidos, a radiodifusão pública também pode procurar responder

\footnotetext{
6 "Problemas e questões de interesse comum", tradução nossa.

7 “Alienação cultural”, tradução nossa.

8 "A introdução de novas tecnologias de comunicação, em especial a televisão, em sociedades tradicionais, raramente tem falhado em abalar costumes centenários, práticas culturais honradas pelo tempo e modos de vida simples, aspirações sociais e padrões econômicos", tradução nossa.
} 
aos variados interesses do público e assim refletir toda a gama de questões atuais da sociedade. (UNESCO, 2001a, p. 12)

No excerto, embora a diversidade de programação seja o enfoque prevalente, observamos uma preocupação com a inclusão e proteção da diversidade cultural. Também podemos perceber que o conceito de pluralidade é confundido com o de diversidade - quando se fala em "diversidade de interesses públicos" e "diversidade dos assuntos discutidos", por exemplo, a preocupação com a manutenção de um espaço de debate de temas de interesse de diversos públicos aproxima o conceito daquele de pluralidade como práxis política.

No documento "Indicadores de qualidade nas emissoras públicas - Uma avaliação contemporânea" (BUCCI et al, 2012), a diversidade é apontada como um dos princípios da radiodifusão pública. $\mathrm{O}$ documento conceitua diversidade cultural:

\begin{abstract}
No âmbito do presente trabalho, a diversidade cultural é entendida como a necessidade de existência, dentro da emissora pública, de uma política e uma prática de respeito à diversidade e suas formas. Esta diversidade é garantida por políticas e práticas internas de respeito à diversidade, tanto nas relações internas, de trabalho, como na programação que vai ao ar. É fundamental que, na programação, esse tópico - diversidade cultural - não se confunda com uma estética meramente pedagógica, destinada a massificar boas maneiras ou a promover a educação cívica. [...] Diversidade cultural tampouco significa a adesão acrítica à cartilha do politicamente correto. [...] A diversidade cultural não está numa orientação paternalista dos conteúdos, mas na presença de uma real polifonia, que reflita a riqueza da vida social. Atenção especial, aqui, deve ser dada às culturas e às manifestações culturais fragilizadas. (BUCCI et al, 2012, p.25)
\end{abstract}

Nos textos da UNESCO, em menor ou maior grau observamos a diversidade cultural como um objeto passivo, estático, que precisa ser protegido, preservado e fomentado. O território da diversidade cultural é o do outro, isolado da seara do "nós"a regra, o "normal", o esperado. De acordo com o pesquisador indo-britânico Homi K. Bhabha (2012), este é justamente o problema com o termo "diversidade cultural". Bhabha (2012) defende que, quando falamos em "diversidade cultural", colocamos o outro em uma categoria monolítica e fixa (BHABHA, 2012). O próprio ato de demarcar o outro como o "diverso" já o deixa em uma posição submissa e reproduz uma relação de dominação (BHABHA, 2012). O autor descreve a diversidade cultural como "reflexo de traços culturais ou étnicos preestabelecidos, inscritos na lápide fixa da tradição" (BHABHA, 2012, p. 20). 
A diversidade cultural é o reconhecimento de conteúdos e costumes culturais pré-dados; mantida em um enquadramento temporal relativista, ela dá origem a noções liberais de multiculturalismo, de intercâmbio cultural ou da cultura da humanidade. A diversidade cultural é também a representação de uma retórica radical da separação de culturas totalizadas que existem intocadas pela intertextualidade de seus locais históricos, protegidas na utopia de uma memória mítica de uma identidade coletiva única. (BHABHA, 2012, p. 63)

Bhabha (2012) explica que, dentro de qualquer comunidade, as pessoas têm identidades múltiplas - além de sua etnia, por exemplo, possuem gênero, orientação sexual, classe social, afora outras características mais subjetivas e menos categóricas. $\mathrm{O}$ autor explana, também, o conceito de "hibridismo cultural" (BHABHA, 2012). Para Bhabha (2012), quando um povo dominado tem contato com a cultura dominadora, o que surge do encontro-embate é um terceiro elemento cultural - a cultura não é mais como era antes do contato com o dominador, mas também não é uma cópia passiva da cultura dominante. Este processo constitui a tradução cultural: a pessoa dominada traduz a cultura dominante por meio das lentes de sua própria cultura (BHABHA, 2012). A tradução cultural é um terceiro momento - não é o momento inicial da cultura "intocada", e nem é a reprodução exata da cultura dominadora. O hibridismo cultural é nem lá, nem cá, e é neste entre-local que se encontram as culturas dominadas (BHABHA, 2012).

O autor propõe, assim, o conceito de "diferença cultural”. De acordo com Bhabha (2012),

\footnotetext{
A diversidade cultural é um objeto epistemológico - a cultura como objeto do conhecimento empírico - enquanto a diferença cultural é o processo da enunciação da cultura como conhecível, legítimo, adequado à construção de sistemas de identificação cultural. (BHABHA, 2012, p. 55)
}

A noção de diferença cultural compreende que as culturas estão em constante mutação, e que são capazes de traduzir influências de outras culturas de forma ativa (BHABHA, 2012). Esta conceituação enxerga os sujeitos dentro de sua complexidade e diferentes identidades (BHABHA, 2012). A diversidade é uma categoria comparativa nós e eles -, enquanto a diferença é um processo de significação (BHABHA, 2012). O conceito de diversidade cultural possui saudosismo a um passado que não é 
necessariamente um símbolo fiel àquela cultura, e sim uma estratégia de dominação de sua representação (BHABHA, 2012).

Do ponto de vista epistemológico, a mudança do conceito de diversidade para diferença implica que as culturas não devem ser vistas como monolíticas e passivas e que os sujeitos não devem ser tratados dentro da estrutura binária que orienta toda a sociedade ocidental - no caso em questão, os pares sujeito/cultura, presente/passado, tradição/modernidade (BHABHA, 2012). A cultura deve ser historicizada, os sujeitos reconhecidos dentro de suas complexidades (BHABHA, 2012).

Neste trabalho, propomos a noção de diferença cultural como uma atualização do termo "diversidade cultural". Assim, consideramos que um dos princípios que devem orientar a radiodifusão pública é o do respeito e valorização à diferença cultural, que compreende as diferentes culturas como complexas e em constante mudança, e os sujeitos como agentes de sua própria história e possuidores de identidades que vão muito além de sua identidade cultural.

\subsection{Indicadores de pluralidade}

Com base na conceituação de pluralidade na radiodifusão pública a que chegamos, criamos três indicadores para medir a pluralidade na televisão pública: 1) protagonismo indígena; 2) contextualização histórica; 3) posicionamento contrahegemônico.

Abaixo, explanaremos as categorias de análise que utilizaremos para contemplar estes indicadores. É importante frisar que descreveremos as categorias, relacionando-as aos principais indicadores que refletem, mas as categorias podem refletir secundariamente mais de um indicador, como demonstra o quadro dois (p. 42).

\subsubsection{Origem da produção}

Relaciona-se a quem produziu o material, uma pessoa indígena ou nãoindígena. Essa categoria diz respeito ao primeiro indicador, protagonismo indígena, e ao posicionamento contrahegemônico. Desejamos compreender, com essa categoria, se a TV Brasil está abrindo espaço para produções indígenas, qual a percentagem da programação realizada por indígenas e por não-indígenas, e se a televisão abre espaço para que indígenas pautem suas próprias demandas. 


\subsubsection{Olhar}

Esta categoria define qual o olhar preponderante no conteúdo da programação, indígena ou não indígena. O olhar é o ponto de vista do conteúdo. Nesta categoria, buscaremos identificar de quem e para quem o conteúdo se destina. O olhar pode ser interno, quando um conteúdo apresentar uma visão indígena das culturas e modos de vida, ou externo, quando apresentar uma visão não-indígena das culturas, colocando as pessoas indígenas no local do outro. Um olhar indígena é dado por assuntos de interesse de pessoas indígenas, pautas para, e não sobre indígenas. $\mathrm{O}$ olhar também pode ser identificado pelo enfoque dado pelo material - a pessoa indígena é vista como o diferente, o estrangeiro, ou é respeitada como sujeito?

O critério relaciona-se ao primeiro indicador, protagonismo indígena, pois permite que observemos se os conteúdos da TV Brasil estão priorizando o olhar indígena.

\subsubsection{Data original de exibição}

É a data quando o conteúdo foi exibido pela primeira vez. É uma categoria ligada ao segundo indicador de pluralidade, a contextualização histórica. Com este indicador, pretendemos saber se a frequência dos conteúdos com temáticas indígenas aumenta com a proximidade do Dia do Índio ou dos Jogos Mundiais Indígenas, ou se mantem-se estável durante o ano. Também iremos investigar se houve mudanças ao longo dos anos na frequência de conteúdos com temática indígena, contextualizando os momentos.

\subsubsection{Fontes}

São as vozes que aparecem nos conteúdos. Podem ser indígenas, caso em que iremos especificar o gênero - masculino ou feminino - e a faixa etária - crianças, jovens, adultos, idosos; governo, caso em que especificaremos se a fonte é a Funai, a polícia, dentre outros; sociedade, ou seja, pessoas não indígenas, especialistas, políticos, etc.; e mercado, representado por parlamentares ruralistas e fazendeiros. Essa categoria relaciona-se ao segundo indicador, protagonismo indígena, pois as fontes deixam entrever se está ocorrendo silenciamento dos indígenas em suas próprias questões. 


\subsubsection{Duração total do material}

É o tempo total de cada conteúdo, que no final será somado de forma geral e por gênero televisivo, para compreendermos quais as médias mensais e anuais de horas de conteúdo com temáticas indígenas, e em qual gênero televisivo se concentram. Desejamos com isso comparar o desempenho da TV Brasil ano a ano na exibição de temáticas indígenas. Essa categoria relaciona-se ao terceiro indicador de pluralidade, posicionamento contrahegemônico, pois, como demonstramos no capítulo três, na mídia dita comercial as pessoas indígenas são silenciadas e invisibilizadas. Queremos saber se o mesmo ocorre no tempo de programação na TV Brasil.

\subsubsection{Temáticas}

São os temas dos conteúdos, explicitados por três palavras-chave - a primeira expressando de forma geral o assunto, e as outras duas citando especificidades. Como a variedade de temáticas abordadas pode ser inúmera, essa categoria ficará em aberto, permitindo-nos atribuir substantivos que mais se adequem a cada conteúdo examinado. Relaciona-se ao terceiro indicador de pluralidade, posicionamento contrahegemônico, pois é por meio desta categoria que poderemos compreender as temáticas abordadas pela TV Brasil no tocante a indígenas, para, então, investigarmos se esta abordagem é diferente daquela da mídia dita comercial.

\subsection{Indicadores de diferença}

Os indicadores de diferença na televisão pública são os seguintes: 1) Complexificação das culturas; 2) Sujeitos multi identitários; 3) centralidade narrativa e autorrepresentação.

As categorias de análise que iremos utilizar para contemplar estes indicadores são:

\subsubsection{Gêneros televisivos}

São os gêneros dos conteúdos com temática indígena exibidos na TV Brasil. Arlindo Machado (2009) explica que os gêneros são formas de organizar as ideias, aglutinar os pensamentos, técnicas e linguagens de um determinado meio.

Num certo sentido, é o gênero que orienta todo o uso da linguagem no âmbito de um determinado meio, pois é nele que se manifestam as tendências expressivas mais estáveis e mais organizadas da evolução de um meio, acumuladas ao longo de várias gerações de enunciadores. (MACHADO, 2009, p. 68) 
Em sua obra "A televisão levada a sério", Arlindo Machado (2009) divide os gêneros televisivos em formas fundadas no diálogo, narrativa seriada, vozes do telejornal, transmissão ao vivo, videoclipe e outras formas musicais, grafismo televisual e poesia na tela (MACHADO, 2009). Com base nas categorias estabelecidas pelo autor, na categorização utilizada em Valente (2009) e em nosso estudo exploratório da programação da TV Brasil, chegamos a seguinte categorização dos gêneros televisivos:

Jornalismo: programações que se enquadram no gênero jornalístico, como telejornais, programas jornalísticos, séries de reportagens e reportagens especiais.

Cultural: inclui todas as programações relativas às artes e conteúdos que não são jornalísticos, mas não são ficção (VALENTE, 2009). Nesse gênero, estão os programas de documentários, sobre regiões do Brasil, musicais e variedades.

Debates e entrevistas: programas com formato de entrevista ou debate sobre temas específicos, como o "3 a 1" e o "Ver TV".

Ficção: grande parte dos conteúdos ficcionais apresentados na TV Brasil são baseados em fatos históricos, com híbridos entre o documentário e a ficção. Colocamos nesta categoria conteúdos cuja prevalência temporal decorra de encenação: dramaturgia, filmes, séries e híbridos.

Infantil: programações voltadas para o público infantil. Inclui desenhos animados, séries e episódios de programas voltados para as crianças.

O gênero televisivo é uma categoria de análise relacionada ao segundo indicador de diferença, sujeitos multi identitários. Mapeando os gêneros da programação relacionada às populações indígenas, desejamos saber se há regularidade de pautas indígenas na programação da EBC e se há concentração em algum dos gêneros, para compreender se ocorre uma divisão complexa entre os gêneros televisivos que abordam indígenas.

\subsubsection{Enquadramento}

A categoria enquadramento diz respeito à abordagem do conteúdo com relação às pessoas indígenas: se positiva, neutra, ou negativa. Uma abordagem positiva seria aquela favorável às populações indígenas, sensível às suas causas e partindo do seu ponto de vista. A abordagem negativa seria aquela que privilegiasse outras versões e pontos de vista antagônicos às causas e questões indígenas. Abordagens neutras seriam as que não favorecessem ou desfavorecessem indígenas. Utilizaremos, como 
subcategorias, o papel das pessoas indígenas na programação - se agente, vilão, vítima, ou nenhum papel. Esta categoria relaciona-se à centralidade narrativa e autorrepresentação.

\subsubsection{Estereótipo}

Nesta categoria, buscaremos determinar se as representações dos indígenas são trabalhadas de forma estereotipada e fetichizada. De acordo com o doutor em psicologia social e professor da Universidade Federal da Bahia Marcos Emanoel Pereira (2002), o estereótipo é uma forma de categorização que analisa o mundo antes mesmo de observá-lo, atribuindo características pré-determinadas a diferentes grupos. No próximo capítulo, na contextualização das relações raciais, aprofundaremos os conceitos de estereótipo e fetichização.

Nossa preocupação com a categoria estereótipo é identificar traços, nos textos verbais e não-verbais, de estereotipização das pessoas indígenas, no sentido de recorrer a simplificações e categorias imbuídas de preconceitos para representá-los. Assim, iremos classificar os texto verbais e não-verbais dos conteúdos de acordo com os estereótipos atribuídos às pessoas indígenas, como bom selvagem, dependente, ingênuo ou fetichizado. O estabelecimento da fetichização se dára no âmbito da imagem, por um foco exagerado em indumentárias, imaginários, ritos, dentre outros, que substituem o sujeito, objetificando-o, silenciando-o e anulando-o. Caso o conteúdo apresente uma construção complexa das personagens indígenas, sem a presença de estereótipos e simplificações, iremos classificá-lo como complexo.

Esta categoria relaciona-se ao primeiro indicador de diferença, complexificação das culturas, e ao segundo, sujeitos multi identitários, pois permite observar se a representação de indígenas está sendo simplificada, anulando os sujeitos e descontextualizando suas histórias.

\subsubsection{Olhar}

Como explanado nos indicadores de pluralidade, o olhar permite compreender de quem e para quem o conteúdo se destina. É o ponto de vista de um conteúdo. Relaciona-se também ao segundo indicador de diferença, sujeitos multi identitários, pois uma prevalência de olhares externos indicaria uma simplificação dos sujeitos e suas culturas. 


\subsubsection{Origem da produção}

Nesta categoria, já explanada nos indicadores de pluralidade, buscaremos determinar a origem da produção dos conteúdos - indígena ou não-indígena. Relacionase ao terceiro indicador de diferença, centralidade narrativa e autorrepresentação, pois permite observar se a TV Brasil abre espaço para produções indígenas.

\subsubsection{Fontes}

Como explanado nos indicadores de pluralidade, as fontes são as vozes nos conteúdos. Relacionam-se ao terceiro indicador de diversidade, centralidade narrativa e autorrepresentação, pois determina as fontes prevalentes nos conteúdos da TV Brasil. Isso possibilita compreendermos se os indígenas têm voz na TV Brasil ou se há alguém falando por eles - e, nesse caso, quem está falando.

$\mathrm{O}$ quadro abaixo resume os indicadores e as categorias que se relacionam a cada um. Importante frisar que, embora tenhamos delimitado as categorias que mais se relacionam a cada indicador, elas não são fechadas em si, podendo dialogar e transbordar em outros indicadores que não os apontados.

Quadro 2 - Indicadores de Pluralidade e Diferença

\begin{tabular}{|c|c|c|}
\hline \multirow{11}{*}{ Indicadores de pluralidade } & \multirow{4}{*}{ Protagonismo indígena } & Origem da produção \\
\hline & & Olhar \\
\hline & & Enquadramento \\
\hline & & Estereótipo \\
\hline & \multirow{2}{*}{ Contextualização histórica } & Data original de exibição \\
\hline & & Fontes \\
\hline & \multirow{5}{*}{$\begin{array}{l}\text { Posicionamento } \\
\text { contrahegemônico }\end{array}$} & Origem da produção \\
\hline & & Enquadramento \\
\hline & & Estereótipo \\
\hline & & Duração total do material \\
\hline & & Temáticas \\
\hline \multirow{8}{*}{ Indicadores de diferença } & \multirow{4}{*}{$\begin{array}{l}\text { Complexificação das } \\
\text { culturas }\end{array}$} & Gênero televisivo \\
\hline & & Enquadramento \\
\hline & & Estereótipo \\
\hline & & Temáticas \\
\hline & \multirow{2}{*}{ Sujeitos multi identitários } & Estereótipo \\
\hline & & Olhar \\
\hline & \multirow{2}{*}{$\begin{array}{l}\text { Centralidade narrativa e } \\
\text { autorrepresentação }\end{array}$} & Fontes \\
\hline & & Origem da produção \\
\hline
\end{tabular}

Fonte: Elaboração própria. 
Neste capítulo realizamos a delimitação dos procedimentos metodológicos que irão guiar a pesquisa e conceituamos pluralidade e diferença na radiodifusão pública, criando indicadores que irão nortear o nosso olhar. No próximo capítulo, faremos a contextualização histórica e um resgate teórico sobre as populações indígenas, relações raciais no Brasil e a radiodifusão pública brasileira. 
antropóloga, que trabalhou por três anos assessorando associações de mulheres indígenas, explica que as pautas dos movimentos de mulheres indígenas é diferente das pautas feministas não-indígenas urbanas, mais baseadas em uma noção individual dos direitos da mulher (SANTOS, 2012). As pautas das mulheres indígenas relacionam-se a questões que envolvem os filhos, a família, a comunidade e o território.

Além das violências externas, como estupros e exploração sexual, as mulheres e meninas indígenas sofrem com violência doméstica, violências decorrentes do alcoolismo - doença que se alastra nas comunidades indígenas - e doenças sexualmente transmissíveis (SANTOS, 2012). Algumas práticas, como troca de esposas e casamentos arranjados, ainda acontecem em algumas culturas (SANTOS, 2012). O movimento de mulheres indígenas reivindica mais participação nas decisões políticas das comunidades e políticas públicas específicas para elas. $\mathrm{Na}$ saúde, reivindicam educação sexual para as mulheres aldeadas e autonomia reprodutiva. Santos (2012) afirma que, como as populações indígenas estão em constante ameaça, as políticas públicas indigenistas e as comunidades incentivam uma alta taxa de natalidade, não oferecendo métodos contraceptivos para as mulheres indígenas aldeadas. As pautas também englobam educação e oportunidades para as mulheres urbanas. De acordo com Santos (2012):

\footnotetext{
As mulheres têm abordado de forma corajosa alguns temas polêmicos, como o controle da sexualidade por parte dos maridos, o direito de escolher quando ter relações sexuais ou mesmo a preferência das famílias por filhos homens. Para as indígenas, o sentido de equanimidade de seu movimento reflete-se em políticas concretas que dêem conta dos problemas que atingem as mulheres indígenas de forma cada vez mais intensa. (SANTOS, 2012, p. 101)
}

Dessa forma, priorizar fontes masculinas demonstra-se hegemônico e não valoriza a multitude de vozes que compõem as populações indígenas. Os direitos das mulheres indígenas são uma pauta que poderia ser discutida e facilitada pela TV pública. No período, duas programações discutiram a questão da mulher indígena: o programa "Mais Direitos Mais Humanos" de 01/11/2014, intitulado "Mulheres Indígenas e Diversidades", e o episódio "Mulheres da Amazônia”, exibido no programa "Nova Amazônia" em 05/06/2013 - ambos com olhar interno.

Quanto à faixa etária, dois conteúdos discutiram a infância entre indígenas, ambos do programa “TV Piá": o episódio "Uma palmada, vale ou não vale?”, exibido 
em 19/09/2010, e "Brincadeiras: criançada da escola indígena Pataxó", de 03/10/2010. É interessante frisar que ambos os conteúdos tiveram olhar externo: apresentaram crianças não-indígenas conhecendo crianças indígenas - o que, do ponto de vista da diferença cultural, é negativo. Com relação à velhice, duas programações discutiram o assunto: a reportagem "Idosos Guarani Kaiowá", exibida no quadro "Outro Olhar", em 06/03/2012, e o documentário "Presente dos Antigos", exibido no programa "docTV" de 31/05/2012, ambos com olhar interno.

Na categoria origem da produção, quando separamos as produções indígenas das não-indígenas, percebemos que, nas produções não-indígenas, a qualidade da programação, do ponto de vista da pluralidade e da diferença cultural, decai. A percentagem de conteúdos que abordam pessoas indígenas como agentes diminui, e surgem abordagens neutras e que tratam o indígena como vilão. A percentagem de conteúdos que representam indígenas de forma complexa se mantém, mas as representações passam a vir acompanhadas de estereótipos e fetichização, inexistentes nas produções indígenas.

No tocante às fontes dos conteúdos de produção não-indígena, ao contrário do observado na totalidade dos conteúdos, a principal fonte é a sociedade. Tem mais voz as fontes ligadas à origem de produção do conteúdo - por exemplo, narradores e apresentadores -, seguidas por especialistas. Ou seja, nas produções não-indígenas, a TV Brasil está falando pelas pessoas indígenas. Este fato é negativo do ponto de vista do protagonismo indígena e da centralidade narrativa e autorrepresentação. Também apresenta um posicionamento hegemônico, já que, na mídia dita comercial, as pessoas indígenas são silenciadas e outras fontes falam por elas (MOURA, 2001; MELO, 2003; KLEIN, 2008; BRANDÃO, 2009; ALECRIM, 2013).

A segunda fonte privilegiada nos conteúdos de produção de origem nãoindígena são os próprios indígenas. Nos conteúdos com fontes indígenas, é interessante ressaltar que homens de todas as faixas etárias têm precedência sobre mulheres. Do ponto de vista da pluralidade, como já argumentamos, essa valorização das vozes masculinas apresenta posicionamento hegemônico. Da perspectiva da diferença cultural, silencia as diferentes vozes das populações indígenas.

Os dados das produções não-indígenas nos levam à compreensão que, de regra, produções indígenas são mais interessantes do ponto de vista da pluralidade e da diferença cultural do que produções não-indígenas. Compreendemos que isto ocorre por três razões. Em primeiro lugar, pela natureza do ato: abrir espaço para que grupos 
historicamente excluídos dos processos decisórios e do acesso aos meios de comunicação apresentem seus conteúdos, quaisquer que sejam, é abrir espaço para protagonismo daquela minoria e adotar um posicionamento contrahegemônico. Coloca as pessoas em posição de centralidade narrativa e permite que se autorrepresentem. Em segundo lugar, porque o olhar interno permite representações mais condizentes com a realidade e menos recheadas de preconceitos e simplificações. Em terceiro lugar, porque abrir espaço para uma minoria falar sobre si mesma, decidindo o conteúdo e para quem se direciona sua mensagem, é respeita-la como parte do tecido social e enxergá-la em sua complexidade.

Os conteúdos de produção indígena se inseriram, massivamente, no quadro “Outro Olhar", do jornalístico "Repórter Brasil”, e no programa “A’Uwe”. Outra porta de entrada para conteúdos indígenas, em menor escala, foi a programação voltada à exibição de documentários. Ou seja, apenas dois gêneros, jornalismo e documentários, receberam programação produzida por indígenas. Do ponto de vista da diferença cultural, não abrir espaço em outros gêneros, como infantil e ficção, por exemplo, é negar a complexidade das culturas indígenas e de seus sujeitos. Embora se possa argumentar que a abertura depende do que está sendo produzido por indígenas, o papel da televisão pública também é o de fomentar estéticas e abordagens que não cabem na TV dita comercial, fornecendo o espaço e os instrumentos para que esses objetivos sejam alcançados (BUCCI et al, 2012).

Por gênero, jornalismo apresentou o maior índice de conteúdos produzidos por indígenas (12\%), o que é positivo do ponto de vista do protagonismo indígena e da centralidade narrativa e autorrepresentação. No entanto, $22 \%$ das matérias jornalísticas apresentam indígenas no papel de vilão ou vítima e não complexificam os sujeitos uma percentagem alta para uma emissora pública. A principal fonte nos conteúdos jornalísticos é a sociedade, o que, do ponto de vista da pluralidade, é negativo, pois retira o protagonismo indígena e apresenta posicionamento hegemônico. As fontes indígenas constituem 36\% das fontes, o menor índice dentre todos os gêneros. Dentre as fontes indígenas, homens de todas as faixas etárias são priorizados, seguidos por mulheres idosas, adultas e crianças. Não há vozes de mulheres jovens. O gênero também apresenta a maior percentagem de imagens fetichizadas (19\%) - o que pode ser explicado pela cobertura de offs - e a maior percentagem de olhares externos.

Os limites para a cobertura jornalística de temáticas indígenas na TV Brasil, assim, demonstram-se nos conteúdos com tempo curto, temáticas relacionadas à 
violência e denúncias, na escolha de fontes, na cobertura de offs e na priorização do olhar externo. As possibilidades surgem nas perspectivas de abertura de espaço para conteúdos indígenas e de tratar de temáticas de maneira contrahegemônica, priorizando o ponto de vista indígena.

O gênero cultural teve uma das melhores estatísticas de enquadramento abordagem positiva em 96\% dos conteúdos e papel único de agente em 79\%. Estes números são positivos do ponto de vista da pluralidade, por apresentarem protagonismo indígena e posicionamento contrahegemônico. Na perspectiva da diferença cultural, colocam as pessoas indígenas na centralidade da narrativa. Os programas culturais foram os únicos que apresentaram olhar interno superior ao externo. Porém, o gênero escorrega ao se utilizar de estereótipos, especialmente o de bom selvagem e dependente do Estado. As temáticas associadas a estereótipos no gênero cultural são cultura, temas históricos e encontro cultural.

A principal fonte das programações culturais foram as populações indígenas, que responderam por $62,5 \%$ das fontes. No entanto, homens adultos ainda são as principais vozes, o que não quebra a hegemonia dentre as fontes indígenas e silencia a diversidade dos sujeitos. É interessante frisar que, no gênero cultural, não houve espaço para fontes ligadas ao governo ou mercado, o que apresenta posicionamento contrahegemônico.

Observamos que os conteúdos do gênero cultural podem ser divididos em seis categorias, a depender das temáticas que abordam: conteúdos históricos, onde há o resgate de algum aspecto da história das pessoas indígenas; conteúdos de denúncia, que apresentam violências contra um determinado povo ou aldeia; programas estilo desbravador, onde o foco está no apresentador enquanto este "desvenda" uma cultura; conteúdos sobre cinema ou música, em que um artista fala sobre sua obra; programas relacionados à natureza, que tem pessoas indígenas como pano de fundo; e conteúdos que focam nos modos de vida das pessoas indígenas.

Os limites para representações plurais e que respeitem a diferença no gênero cultural na TV Brasil demonstram-se, principalmente, nas categorias desbravador, históricos, natureza e denúncia. Os programas do estilo desbravador demonstraram respeito pelas culturas e mostraram suas complexidades, o que é positivo do ponto de vista da contextualização histórica e da complexificação das culturas. Porém, programas desbravadores colocam os povos indígenas na categoria automática do outro. $\mathrm{O}$ foco desse estilo de programação é no apresentador e em suas sensações, descobertas, 
aprendizados, o que retira o protagonismo indígena, a centralidade narrativa e a possibilidade de autorrepresentação. Os programas desbravadores muitas vezes utilizam-se de estereótipo de bom selvagem e dependente, além de fetichizarem as imagens das pessoas. Já os programas históricos e de denúncia acabam por vitimizar as populações indígenas, aplicando estereótipos tidos como simpáticos aos indígenas, como bom selvagem. Os programas sobre a natureza apresentam as pessoas indígenas como pano de fundo para um cenário "exuberante", reproduzindo as abordagens dos telejornais da televisão dita comercial (COSTA, 2011).

As possibilidades surgem na categoria modos de vida, que constituem a maior parte da programação. Essas programações apresentam diferentes culturas, tratando de temáticas como dança, música, direitos e literatura. Do ponto de vista da pluralidade, respeitam o protagonismo indígena e apresentam posicionamento contrahegemônico. Da ótica da diferença cultural, representam as culturas de forma complexa, abrem espaço para as diversas vozes indígenas e colocam as populações indígenas no centro da narrativa ou permitem a autorrepresentação.

O gênero ficção apresentou algumas das representações mais pobres do ponto de vista da pluralidade e da diferença cultural. Neste gênero, apesar das abordagens serem positivas, as pessoas indígenas são colocadas como agentes em apenas $25 \%$ dos conteúdos. O principal papel das pessoas indígenas é o de vítima, e o estereótipo do bom selvagem aparece em 50\% dos conteúdos. Também é o gênero com menor índice de representações complexas $(25 \%)$. Da perspectiva da pluralidade, o gênero ficção não apresenta protagonismo indígena ou posicionamento contrahegemônico, embora demonstre contextualização histórica. Da ótica da diferença cultural, as programações de ficção da TV Brasil, em geral, não apresentaram complexificação das culturas, sujeitos multi identitários, centralidade narrativa ou autorrepresentação.

$\mathrm{Na}$ questão das fontes, a ficção prioriza mulheres indígenas adultas e jovens. Essa priorização pode indicar uma exploração do corpo e sexualidade da mulher indígena, como visto nos conteúdos da mídia dita comercial (SILVA, 2007). Como nos conteúdos comerciais, a mulher é tida como um prêmio para o colonizador, um território a ser conquistado, em uma metáfora para a colonização (SILVA, 2007).

Novamente, isso demonstra uma dificuldade da TV Brasil em lidar com temáticas relacionadas a temas históricos, dominação, violência e embate cultural sem anular os sujeitos que sofreram tais violências - um dos limites para o gênero ficção. A emissora pública precisa ser capaz de fazer ficção sem apelar para as estratégias 
utilizadas pela mídia que visa ao lucro, como violência gratuita e exploração do corpo feminino.

O gênero debates e entrevistas teve o menor número de abordagens positivas dentre os gêneros da TV Brasil. Em geral, as representações de pessoas indígenas, do ponto de vista da pluralidade, foram negativas, com pouco protagonismo e posicionamento hegemônico. Do ponto de vista da diferença, em geral, não apresentaram complexificação das culturas, sujeitos multi identitários, centralidade narrativa ou autorrepresentação.

Identificamos dois tipos de programas de debates e entrevistas: aqueles que promovem debates para discutir um tema corrente e os que debateram temáticas específicas, não relacionadas diretamente ao momento político e social. O pior do gênero figurou na primeira modalidade, e na segunda estiveram algumas das programações com representações mais positivas da TV Brasil.

$\mathrm{Na}$ primeira categoria, chamou a atenção o número de programas que discutiram questões indígenas atuais à época da exibição sem convidar fontes indígenas. Como na mídia dita comercial, onde indígenas são silenciados (MOURA, 2001; MELO, 2003; KLEIN, 2008; BRANDÃO, 2009; ALECRIM, 2013), a maior parte das programações contou com especialistas ou representantes do governo para falar pelas pessoas indígenas sobre suas questões, em um posicionamento hegemônico e silenciador. O mercado também teve bastante espaço nos programas de debates e entrevistas, na forma de deputados ruralistas e representantes do agronegócio. Neste sentido, é interessante relembrar a resposta de Laurindo Leal Filho, apresentador do programa "Ver TV" - e, à época, ouvidor da EBC -, sobre a polêmica que um dos episódios do programa causou, ao discutir a não-renovação da concessão da RCTV pela Venezuela sem debatedores críticos à medida (VALENTE, 2009). Leal Filho respondeu afirmando que a diversidade pode ser promovida pela "visibilidade de posições que normalmente não estão presentes na arena dos meios de comunicação" (VALENTE, 2009, p. 138). Ou seja, na TV pública a complementariedade se dá não pela abertura de espaço para ouvir todos os lados, ou pela divisão meticulosa do tempo de fala entre todos os lados envolvidos. Na TV pública, a complementariedade se dá pela priorização de vozes e enfoques que não têm lugar na mídia dita comercial. Afinal, a "grande mídia" já privilegia o outro lado.

Assim, um dos limites que se coloca ao gênero debates e entrevistas é alçar as pessoas indígenas a posições de agência e parar de trata-las como vítimas, incapazes ou 
dependentes de representantes. Podemos citar como exemplo deste tratamento o programa "Brasilianas.org".

A outra categoria de programas de debates e entrevistas convidou debatedores indígenas para falarem sobre um assunto. Os episódios foram o "A construção das desigualdades sociais na historia do Brasil", exibido no programa "EntreLivros" em 19/04/2014; e "Invisibilidade dos indíos: a falta de programas sobre as culturas índígenas na TV", do programa "Ver TV", exibido em 13/11/2013. Ambos os conteúdos foram de denúncia e trataram de violências, simbólicas e físicas; no entanto, as pessoas indígenas foram tratadas de forma complexa, como agentes, sem serem vitimizadas ou estereotipadas. Essa é uma das possibilidades do gênero debates e entrevistas: mergulhar em temáticas que, em outros gêneros, recebem tratamento raso e negativo do ponto de vista das representações indígenas, e abordá-los de forma complexa.

O gênero infantil foi o mais rico em representações de pessoas indígenas. Todas as abordagens foram favoráveis e as pessoas indígenas foram representadas como agentes e sujeitos complexos. O ponto baixo da programação infantil foi a série "Turma do Pererê", que apresenta estereótipo de bom selvagem, imagem fetichizada e tratamento genérico. O ponto alto foram os episódios do "TV Piá", um programa onde crianças comandam a condução das pautas.

Um dos limites que se coloca ao gênero infantil é o olhar externo - mesmo nas programações de qualidade, o olhar ainda é de alteridade. Do ponto de vista da pluralidade, a prevalência de olhar externo retira o protagonismo indígena. Pela ótica da diferença, enxergar o diferente como o outro é reproduzir uma lógica de dominação (BHABHA, 2012). Outro limite que se coloca é o número reduzido de conteúdos, concentrados nos anos de 2010 a 2012. É necessário voltar a produzir programação voltada para os públicos infantis que abordem e que sejam voltadas para as crianças indígenas.

$\mathrm{Na}$ seara das possibilidades, a programação infantil foi o megafone para crianças indígenas na TV Brasil. A distribuição das fontes priorizou vozes negligenciadas nos outros gêneros televisivos, o que, do ponto de vista da pluralidade e da diferença, é muito positivo. O gênero infantil também foi o que trouxe maior diversidade de temáticas, rompendo o monopólio das pautas relacionadas ao momento político, direitos, história ou apresentação de culturas. Isso demonstra complexificação das culturas indígenas, representando estas populações em suas múltiplas identidades. 
Não nega a necessidade de resistir, mas apresenta pessoas indígenas para além de suas lutas e questões.

Com relação à frequência da programação, observamos na pesquisa quantitativa que o número de conteúdos com temática indígena aumenta no mês de abril, quando se comemora o Dia do Índio. Outros meses com índice alto de programação são maio e novembro. No resto do ano, a programação mantém-se estável. Nos meses de maio, observamos que o aumento refletiu a situação em Belo Monte - a maior parte dos conteúdos foi veiculada em 2013 e é do gênero jornalismo. Em novembro a programação concentrou-se em 2012, e também seguiu o mesmo padrão: maioria de conteúdos jornalísticos sobre a situação dos Guarani Kaiowá.

Estes dados podem demonstrar que a TV Brasil não conseguiu pautar a presença indígena na programação ao longo do ano. Os picos de frequência evidenciam que as temáticas indígenas são ditadas pelo contexto político. Da perspectiva da pluralidade, embora a contextualização seja positiva, lembrar-se das populações indígenas apenas quando estão no holofote é um posicionamento hegemônico. Da ótica da diferença cultural, deixar o contexto pautar a presença indígena reduz essas pessoas às suas questões. A TV pública necessita ter a preocupação de representar pessoas indígenas o ano inteiro, independente do contexto político, de forma a perpassar a programação.

Nos meses de abril, a intensidade da programação aumenta com a proximidade do Dia do Índio. No entanto, a qualidade dos conteúdos, do ponto de vista da pluralidade e da diferença cultural, não melhora. Do dia 16 ao dia 23 , a maioria dos conteúdos é de produção não-indígena e apresenta visão externa, e 47\% apresentam os estereótipos de bom selvagem, dependente, tratam as populações indígenas de forma genérica ou fetichizam suas imagens. Os conteúdos com referência direta ao Dia do Índio estão dentre as programações mais fracas do ponto de vista da pluralidade e da diversidade cultural. Todos apresentam olhar externo e produção não-indígena. Um dos conteúdos, um debate promovido pelo Repórter Brasil ("Repórter Brasil debate direitos dos índios", 19/04/2013), apresenta representação complexa, com a advogada Joênia Wapixana falando sobre o Dia do Índio e direitos. De resto, todos os conteúdos apresentaram representações de indígenas como dependentes ou bons selvagens, fetichizaram as suas imagens e trataram os povos de modo genérico. Nestes conteúdos, as pessoas indígenas são apresentadas como submissas e agradecidas, servindo de pano de fundo para autoridades e especialistas. Um exemplo disso é o conteúdo jornalístico 
"Museu do índio do Rio completa 60 anos" (19/04/2013), da edição matutina do "Repórter Brasil". A repórter, em link ao vivo, entrevista o diretor do Museu do Índio sobre a questão linguística indígena, enquanto homens indígenas realizam uma dança ao fundo.

Observamos, assim, que quando o conteúdo se relaciona ao Dia do Índio a TV Brasil tem dificuldades de tratar pessoas indígenas como protagonistas ou contextualizar suas lutas e histórias, recorrendo a posicionamentos hegemônicos para "celebrar" a data. Na busca pela pluralidade, emissoras públicas devem ressaltar o caráter histórico e de luta de datas de consciência étnica, racial ou de gênero. O Dia do Índio foi fruto de uma carta de recomendação do $1^{\circ}$ Congresso Indigenista Interamericano aos países das Américas, ocorrido no México em 1940 (MUSEU DO ÍNDIO, 2017). A carta instituiu 19 de abril, dia da primeira assembleia do congresso, como uma data para que as questões indígenas fossem estudadas nas escolas (MUSEU DO ÍNDIO, 2017). O esvaziamento deste significado em prol de um caráter celebratório coloca a TV pública como mais um veículo que contribui para o silenciamento das populações indígenas e para a manutenção de estruturas coloniais de dominação.

Ao longo dos anos, a representação indígena mudou na TV Brasil. De 2008 até 2010, as principais fontes eram mulheres adultas. As temáticas prevalecentes no período foram resistência, terras indígenas, tecnologia. De 2011 a 2013, as temáticas passam a girar em torno de dominação, embora o enfoque da resistência ainda esteja presente. As fontes privilegiadas também mudaram: homens adultos, em 2011 e 2012, e a sociedade, em 2013. Em 2012 e 2013 houve um pico no número de conteúdos relacionados à temática indígena. Nestes anos, como já observamos ao longo de nossa análise, ocorreram algumas das representações mais negativas da TV Brasil. Porém, é interessante notar que, nos anos anteriores, os conteúdos com temáticas indígenas foram muito pontuais. Este fato não é positivo, pois, como política interna de conteúdos, não apresenta posição contrahegemônica e não enxerga as populações indígenas como possíveis telespectadores da TV pública. Nos anos de 2012 e 2013, mesmo que pautados pelo contexto político e social da época, a TV Brasil deu a cara a tapa e produziu conteúdos acerca das populações indígenas. Começou, assim, a engatinhar na noção de incluir as pessoas indígenas em sua programação de forma transversal e definitiva.

O pulo do gato deveria ter acontecido nos anos seguintes, 2014 e 2015. Porém, nestes anos a frequência da programação relacionada a indígenas caiu - principalmente 
no gênero jornalismo, já que muitas das questões dos anos anteriores foram resolvidas. Os temas voltaram a ser "frios" ou relacionados a esportes - o que se dever à Copa do Mundo, em 2014, e aos Jogos Mundiais dos Povos Indígenas, em 2015.

Importante frisar que a cobertura dos Jogos Mundiais dos Povos Indígenas deixou a desejar, em termos de intensidade. Apenas quatro conteúdos tiveram os jogos como temática. As representações, entretanto, foram positivas: as pessoas indígenas foram colocadas como protagonistas e representadas em suas complexidades.

Assim, embora nos anos de 2008 a 2010 as representações de indígenas fossem mais favoráveis do ponto de vista da pluralidade e diferença, em 2012 e 2013 a TV Brasil começou a inclui-las de fato na programação. Este poderia ter sido um primeiro passo para incluir as populações indígenas como parte do público da TV Brasil. Um exemplo de um programa produzido pela emissora que conseguiu incluir indígenas como parte de seu público foi o jornalístico "Caminhos da Reportagem", semanal que apresenta reportagens especiais. Em alguns episódios, "Caminhos da Reportagem" entrevista personagens indígenas sobre os mais diversos assuntos, como voto e ensino superior. Ou seja: as pessoas indígenas não aparecem apenas como pauta; são parte de uma sociedade complexa e têm opiniões sobre diferentes aspectos da realidade. Esse posicionamento precisa ser parte da política interna da emissora. 


\section{Considerações finais}

O objetivo geral deste estudo foi delimitar as representações das populações indígenas na TV Brasil, no período de 2008 a 2015. Para tanto, resgatamos, por meio da ferramenta de busca na página da TV Brasil, as programações veiculadas no período, e assistimos aos conteúdos, classificando-os de acordo com categorias de análise que refletiam indicadores de pluralidade e diferença cultural na radiodifusão pública.

Encontramos 195 conteúdos, aos quais assistimos integralmente. O estudo quantitativo deu origem a uma nuvem de palavras, um recurso gráfico para visualização de palavras e temáticas de acordo com sua frequência. A nuvem de palavras serviu como ponte entre a pesquisa quantitativa e a qualitativa, na qual interpretamos as representações das populações indígenas na TV Brasil.

A principal representação que encontramos foi a de homens adultos complexos e agentes, representados em conteúdos jornalísticos com abordagem favorável às populações indígenas, mas apresentando visão externa às culturas e dirigindo-se a pessoas não-indígenas. Esta é uma possibilidade que a TV Brasil apresentou no período, proporcionar um espaço plural e simpático às questões indígenas.

De 2008 a 2015, um período marcado por contextos sociais e políticos violentos e desfavoráveis às populações indígenas, a TV Brasil demonstrou-se uma arena na qual indígenas foram sujeitos de direitos, seus pontos de vista foram favorecidos e suas questões, respeitadas. Neste sentido, a TV Brasil cumpriu a missão de apresentar um ambiente plural. Dar visibilidade às questões indígenas fora da lógica mercadológica ou assistencialista empodera este grupo e dá um primeiro passo rumo à construção de uma televisão pública voltada para a pluralidade de vozes.

De maneira geral, a TV Brasil enxerga as populações indígenas como cidadãs. As diversas culturas são respeitadas e valorizadas, as pessoas indígenas são tratadas de forma complexa, em papeis de agência e como sujeitos de direitos. Essa é outra possibilidade que a programação do período apresentou: fornecer representações de indígenas emancipadas e sem preconceitos.

Porém, a prevalência da visão externa e de produções não-indígenas coloca-se como um limite. Para além de um espaço de quebra de preconceitos e de posicionamentos contrahegemônicos, a radiodifusão pública pode proporcionar um canal que contemple o direito das pessoas indígenas a se representarem e se verem 
representadas, informarem e serem informadas - em suma, um ambiente que contemple o direito de terem acesso bilateral à construção simbólica de suas identidades. Esta é, aliás, uma das missões da radiodifusão pública: incentivar processos para que as pessoas se vejam representadas nas emissoras (BUCCI et al, 2012).

A TV Brasil trata as pessoas indígenas como cidadãs. Precisa, entretanto, tratálas também como público-alvo, potenciais consumidoras das programações da emissora. O olhar externo, a produção não-indígena, os enfoques e temáticas deixam entrever que o principal público-alvo das produções da TV Brasil com temáticas indígenas não são as populações indígenas. A TV Brasil está falando sobre indígenas, mas não está falando com indígenas. É preciso quebrar a lógica hegemônica que coloca as pessoas indígenas como o outro e integrar os povos indígenas como público, e não apenas como pauta.

A falta de diversidade de assuntos dos conteúdos e a concentração no gênero jornalismo também se apresentaram como limites. A TV Brasil encaixou as populações indígenas majoritariamente em pautas "quentes" e noticiário. A maior parte dos conteúdos apresentados não deu profundidade às pessoas para além das grandes questões indígenas, como demarcação de terras e genocídios, ou da apresentação das diferentes culturas. Porém, como fugir destas questões, se ainda hoje as populações indígenas lutam para sobreviver (LUCIANO, 2006)?

A solução não é diminuir a frequência das pautas "quentes", dos conteúdos relacionados às questões indígenas e apresentação de culturas. O desafio é integrar pessoas indígenas de forma transversal, em todos os gêneros televisivos, com abrangência de temáticas, independentemente do contexto social e político. As políticas internas de produção de conteúdo precisam considerar os povos originários o ano inteiro, em todos os gêneros televisivos da TV Brasil. Além disso, as pessoas indígenas precisam aparecer na programação não apenas como um grupo isolado e fechado, como uma categoria de alteridade, mas como parte do tecido social. É necessário acabar com a "caixinha" em que as populações indígenas estão categorizadas e guardadas na TV Brasil para que dela possam sair as pessoas, ocupando os espaços da programação da emissora.

Isso implica que indígenas precisam estar, também, no corpo de funcionários e instâncias decisórias. Agregar grupos de minoria a todas as etapas produtivas de uma emissora pública quebra o binômio nós - eles e permite um olhar interno às representações daquelas pessoas. Talvez uma forma de garantir essa inserção seja por 
meio de cotas nos concursos públicos voltados a preencher os cargos e posições da EBC.

A questão de gênero e faixa etária também se colocou como uma limitação na programação da TV Brasil no período. As principais fontes foram homens adultos, o que silencia a multiplicidade de vozes e identidades que compõem as populações indígenas. É importante que as pessoas indígenas tenham voz na emissora pública, independentemente de seu gênero ou faixa etária - na verdade, quanto maior a situação de vulnerabilidade social, maior espaço devem possuir.

Nas produções não-indígenas as representações, dos pontos de vista da pluralidade e da diferença cultural, tornam-se mais negativas: as pessoas indígenas têm menor espaço como agentes e surgem representações negativas e estereotipadas, como vilão, selvagem, bom selvagem e mentiroso. As fontes prevalentes passam a ser a sociedade, com foco nas fontes ligadas à produção do conteúdo, como repórteres e apresentadores, e especialistas. O local privilegiado das fontes ligadas à sociedade demonstra que, em produções não-indígenas, a TV Brasil está falando por essas pessoas. Além disso, dentre as fontes indígenas, homens de todas as faixas etárias ganham prevalência sobre mulheres e crianças. O silenciamento e o privilégio a vozes que tem mais poder na estrutura social são limites que corroboram a necessidade de integrar indígenas em todas as etapas de produção das programações.

Algumas temáticas apresentaram-se como limitantes: encontro cultural, Amazônia, temáticas históricas, relacionadas à violência e ao Dia do Índio. Na temática encontro cultural, a própria pauta é contrária ao princípio da diferença cultural que apresentamos neste trabalho, uma vez que coloca as culturas em posições estáticas e comparativas. Na temática Amazônia, nenhuma personagem indígena foi apresentada como complexa, o que pode indicar que um limite que se coloca à TV Brasil é representar a relação entre pessoas indígenas e a floresta. Nos temas históricos e relacionados à violência, as pessoas indígenas são tratadas como vítimas e bons selvagens. Os conteúdos com temas com relação direta ao Dia do Índio, em vez de problematizarem as questões indígenas, comemoram a data, colocando o indígena em uma posição submissa e agradecida. As temáticas que se apresentaram como possibilidade foram aquelas que permitiam abordar as pessoas em suas complexidades, como música, literatura e dança.

Uma segunda representação recorrente das populações indígenas foi a de vítima, bom selvagem ou dependente. Percebemos que um limite que se colocou à TV 
Brasil no período, principalmente nos gêneros jornalismo, ficção e debates e entrevistas, foi recorrer a representações teoricamente favoráveis às populações indígenas quando as temáticas giravam em torno de violência ou temas históricos.

Por gênero, jornalismo apresentou como possibilidades a abertura de espaço para conteúdos com produção de origem indígena e o tratamento contrahegemônico das temáticas. Como limites, colocam-se as representações em conteúdos com tempo curto; em temáticas relacionada à violência e denúncias; na priorização de fontes ligadas à sociedade; no uso de fetichização na cobertura de offs; e na priorização de olhar externo.

Os conteúdos do gênero cultural podem ser divididos de acordo com as temáticas que abordam: conteúdos históricos, de denúncia, desbravadores, sobre cinema ou música, sobre a natureza e sobre modos de vida. Os limites surgem nos conteúdos de denúncia e históricos, que vitimizam as populações indígenas; desbravadores, cujo foco no apresentador coloca os povos indígenas na categoria de outro; e sobre a natureza, que colocam indígenas como pano de fundo. As possibilidades emergem na categoria modos de vida, que abordam temáticas diversas, o que corrobora a ideia de que é necessário incorporar pessoas indígenas de maneira transversal na programação.

No gênero ficção a prevalência de mulheres jovens e adultas pode indicar a exploração do corpo e sexualidade da mulher indígena, como ocorre na mídia dita comercial (SILVA, 2007). As representações, em geral, foram marcadas pela vitimização das pessoas. Um desafio que se coloca à emissora pública é fazer ficção sem recorrer a artifícios utilizados pela mídia dita comercial, como violência e exploração do corpo feminino.

No gênero debates e entrevistas, identificamos dois tipos de programações: debates sobre temas atuais e sobre temáticas não relacionadas ao momento político. $\mathrm{O}$ primeiro tipo tratou indígenas como vítimas, incapazes e dependentes, colocando fontes para falar por indígenas. Também abriu bastante espaço para fontes ligadas ao mercado. Tais fatos colocam-se como limites: em emissoras públicas, a complementariedade se dá não pela divisão meticulosa de tempo de fala para todos os lados envolvidos, mas pelo privilégio a fontes silenciadas na mídia dita comercial. Como possibilidades, estão as programações sobre temáticas não relacionadas ao momento político, que, embora tenham tratado de temas como violência e dominação, conseguiram colocar indígenas no papel de agente, sem vitimizá-los. 
No gênero infantil, os limites foram a prevalência do olhar externo e o número reduzido de conteúdos, concentrados entre 2010 a 2012. As possibilidades se demonstram na multiplicidade de vozes e de temáticas no gênero.

Vimos que as representações mudaram com o passar dos anos. De 2008 a 2010, a principal representação era a mulher adulta. Essa representação foi substituída pelo homem adulto, em 2011 e 2012; pelo sujeito silenciado pelas vozes institucionais da emissora e de especialistas, em 2013 e 2014; e de volta a homens adultos, em 2015. $\mathrm{Na}$ maior parte dos anos, indígenas foram as principais vozes, o que apresenta a TV pública como uma possibilidade de inserção de vozes silenciadas na mídia dita comercial. No entanto, a frequência das programações com temáticas relacionadas a indígenas deixa a desejar, mesmo com o boom de conteúdos em 2012 e 2013.

De maneira geral, percebemos que a lógica que a TV Brasil seguiu nas representações das populações indígenas acompanha a nossa tradição de radiodifusão pública. Enquanto no modelo europeu o sistema público surgiu como principal, ditando toda a lógica da radiodifusão, aqui o sistema privado nasceu primeiro, e o público surgiu para complementá-lo. Em nosso modelo, a emissora pública vem sempre para corrigir, consertar, para catar os cacos e organizar a bagunça das mídias ditas comerciais. Dentro desta lógica, mostrar indígenas de forma não preconceituosa e complexa, com abordagens favoráveis, é suficiente. Para ir além, a TV pública deve sair de uma posição em que se percebe como complementar e tomar a iniciativa em ações que realmente rompam paradigmas.

Percebemos que na TV Brasil, até o momento, há muita boa vontade em fazer televisão que contemple pluralidade e diferença cultural. As representações de indígenas como coletivos, em respeito aos diferentes povos, culturas e modos de vida, são favoráveis, mas ainda há o que se avançar nas representações das pessoas. A qualidade das representações também oscila muito de ano a ano, por gênero e, até mesmo, dentro do mesmo gênero televisivo. Isso pode indicar que a TV Brasil está fazendo televisão voltada à pluralidade e diferença cultural das populações indígenas na prática, em um esquema de tentativa e erro. Um desafio que se coloca é capacitar o quadro da EBC, por meio de palestras, cursos, ou mesmo por meio de um manual voltado ao tratamento de minorias nas programações.

Os tempos para radiodifusão pública no Brasil não são favoráveis. Para que a TV Brasil continue na caminhada rumo a representações de populações indígenas que contemplem pluralidade e diferença cultural, a emissora precisa de independência - e 
este é o último e maior desafio que a emissora enfrenta. Só assim, será possível romper com as lógicas coloniais que ainda permeiam as representações de indígenas na mídia, para que, pelo menos no âmbito da Comunicação, possamos começar a dirimir a dívida histórica com os povos indígenas. 


\section{Referências}

AGÊNCIA SENADO. Comissão mista aprova relatório da MP que reestrutura a EBC. Senado, online, 08/12/2016. Disponível em: http://www12.senado.leg.br/noticias/materias/2016/12/08/comissao-mista-aprovarelatorio-da-mp-que-reestrutura-a-ebc. Acessado em 30/12/2016, às 17 h46.

ALECRIM, Wenya. A desintrusão da Terra Indígena Raposa Serra do Sol por meio das lentes da TV Roraima. In: Intercom - Sociedade Brasileira de Estudos Interdisciplinares da Comunicação XVCongresso de Ciências da Comunicaçãona Região Centro-Oeste -Rio Verde-GO - 30/05 a 01/06/2013.

ALMEIDA, Verônica Eloi de. A Muralha e a representação indígena na televisão, na literatura e nas ciências sociais. In: Proa, Revista de Antropologia e Arte, $\mathrm{n}^{\circ} 4$ v. 1 , 2013. Disponível em: http://www.revistaproa.com.br/04/?page_id=100

AMADO, Guilherme. Após 20 anos à frente do Sem Censura, Leda Nagle é demitida da TV Brasil. O Globo, online, 07/12/2016. Disponível em: http://blogs.oglobo.globo.com/lauro-jardim/post/apos-20-anos-frente-do-semcensura-leda-nagle-e-demitida-da-tvbrasil.html?utm_source=Twitter\&utm_medium=Social\&utm_campaign=compartilha r. Acessado em 30/12/2016, às $17 \mathrm{~h} 12$.

ARAÚJO, Joel Zito. Onde está o negro na TV pública? Fundação Cultural Palmares: 2010, 8 p. Disponível em http://www.palmares.gov.br/sites/000/2/download/pesqtv.pdf Último acesso: 08/10/2014, às 10:42.

BACCEGA, Maria Aparecida. O estereótipo e as diversidades. São Paulo: Revista Comunicação e Educação, v. 5, nº 13, set./dez 1998, p. 7-14.

BANDEIRA DE MELO, Patrícia. Sujeitos sem voz: Agenda e Discurso sobre o Índio na Mídia em Pernambuco. Dissertação de mestrado. Universidade Federal de Pernambuco, 2003.

BHABHA, H. K. O local da cultura. Belo Horizonte: Editora UFMG, $1^{\text {a }}$ edição, 1998.

BOBBIO, Norberto. As ideologias e o poder em crise. Brasília: Editora Universidade de Brasília, $4^{a}$ edição, 1995.

BOLÁN, Eduardo Nivón. Las Políticas Culturales En América Latina en el Contexto de la Diversidad. In: GRIMSON, Alejandro; BIDASECA, Karina. Hegemonia Cultura y Politicas de la Diferencia. Ciudad Autónoma de Buenos Aires : CLACSO, 2013.

BOLAÑO, C.; BRITTOS, V. TV pública, políticas de comunicação e democratização: movimentos conjunturais e mudança estrutural. Revista de Economía Política de las Tecnologías de la Información y Comunicación, n. 3, v. X, 2008.

BRANDÃO, Cristina de Jesus Botelho. A construção discursiva da comemoração do dia do índio no museu do índio pela mídia televisiva. Dissertação. Rio de Janeiro: 
Programa de Pós-Graduação em Memória Social da Universidade Federal do Estado do Rio de Janeiro, 2009.

BRASIL. Lei Federal $\mathbf{n}^{\mathbf{0}}$ 11.652. Sete de abril de 2008. Disponível em: http://www.planalto.gov.br/ccivil_03/_ato2007-2010/2008/lei/111652.htm Último acesso: 08/10/2014, às 11:20.

Constituição Federal. 1998.

Decreto-Lei 236/67. 28 de fevereiro de 1967.

Medida Provisória 398. Dez de outubro de 2007.

Medida Provisória 744. $1^{\text {o }}$ de setembro de 2016.

BUCCI, Eugênio. É possível fazer televisão pública no Brasil? Novos estud. CEBRAP, no 88, São Paulo: 2010. Disponível em:

http://www.scielo.br/scielo.php?pid=S0101-33002010000300001\&script=sci_arttext

Último acesso: 08/10/2014, às 11:12.

CARMONA, Beth. A marca da TV pública. In: I Fórum Nacional de Tv's Públicas: Diagnóstico do Campo Público de Televisão. Brasília: Ministério da Cultura, 2006, p. $21-25$.

CARVALHO, Railídia. EBC: Atos no RJ, Brasília e SP denunciam golpe de Temer na empresa. Portal Vermelho: 20 de maio de 2016. Disponível em:

http://www.vermelho.org.br/noticia/281242-8. Acessado em 29/12/2016, às 19h27.

CARVALHO, Vívian de Nazareth Santos; NEVES, Ivânia dos Santos. A "fala errada" dos indígenas nas telenovelas brasileiras: entre o saber e o poder. Rev. Comun. Midiática (online), Bauru/Sp, V.9, N.3, p. 69-85, set./dez. 2014.

CARVALHO, Vívian de Nazareth Santos; NEVES, Ivânia dos Santos. O corpo indígena nas telenovelas brasileiras: memória, nudez e embranquecimento. Revista Redisco: Vitória da Conquista, v. 8, nº 2, p. 88-94, 2015.

CAVALCANTI, Maria Laura Viveiros. O Indianismo revisitado pelo Boi-Bumbá. Notas de Pesquisa. Revista Somanlu, v. 2, edição especial, 2002, p. 127-135.

CONSELHO CURADOR DA EBC. Conselho Curador se posiciona contra mudanças na direção da EBC. Online. 14 de maio de 2016. Disponível em: http://agenciabrasil.ebc.com.br/geral/noticia/2016-05/conselho-critica-rumores-dejornalista-indicado-por-temer-assumir-ebc. Acessado em 29/12/2016, às 18h23.

Informações sobre o Conselho Curador. Disponível em:

www.conselhocurador.ebc.com.br/. Último acesso: 23/09/2015, às 10:30.

COSTA, Vânia Torres. Amazônia e Telejornalismo: Uma Leitura dos Sujeitos nas Narrativas Audiovisuais. II Conferência Sul Americana e VI Conferência Brasileira Mídia Cidadã. Brasil: Belém-PA, 17 a 22 de outubro de 2011. 
COUTO, Andréia Terzariol; PAVAN, Maria Angela. A resistência dos canais alternativos de TV: estudo de caso da TV Comunitária de Campinas - Canal 8. Revista Extraprensa, América do Norte, 1, nov. 2010, 21 p. Disponível em: http://www.revistas.usp.br/extraprensa/article/viewFile/77181/81043 Último acesso: 08/10/2014, às 10:29.

CUNHA, Edgard Teodoro da. Cinema e Imaginação. A Imagem do Índio no Cinema Brasileiro dos Anos 70. Dissertação - Faculdade de Ciências e Letras (FCL). Universidade Estadual Paulista (UNESP). Campus de Araraquara. Araraquara, SP, Brasil, 110 p.

DAMATTA, Roberto. O que faz do brasil, Brasil?. Rio de Janeiro: Rocco, 2001.

DEL BIANCO, Nelia; ESCH, Carlos Eduardo; MOREIRA, Sônia Virgínia. Radiodifusão pública: um desafio conceitual na América Latina. Estudos em Comunicação, $n^{\circ}$ 12, dezembro de 2012, p. 155 - 181.

DIRETORIA-EXECUTIVA DA EBC. Nota sobre a nomeação de um novo diretorpresidente para a Empresa Brasil de Comunicação - EBC. Online. 13 de maio de 2016. Disponível em: a nomeação de um novo diretor-presidente para a Empresa Brasil de Comunicação - EBC. Acessado em 29/12/2016, às 18h23.

ÉBOLI, Evandro. Temer exonera presidente da EBC duas semanas após escolha de Dilma. Jornal O Globo, online, 17/06/2016. Disponível em: http://oglobo.globo.com/brasil/temer-exonera-presidente-da-ebc-duas-semanas-aposescolha-de-dilma-19319660. Acessado em 29/12/2016, às 17h27.

EMPRESA BRASIL DE COMUNICAÇÃO. Site institucional. Disponível em: http://www.ebc.com.br/institucional/conselho-curador. Acessado em 30/12/2016, às $16 \mathrm{~h} 50$.

FENAJ. Trabalhadores da EBC continuam em estado de greve. Portal da FENAJ, online, 24/11/2016. Disponível em: http://fenaj.org.br/trabalhadores-da-ebccontinuam-em-estado-de-greve/. Acessado em 30/12/2016, às $17 \mathrm{~h} 18$.

FOLHA ONLINE. Conheça os personagens da novela "Bicho do Mato". 17/01/2006, 9h23. Disponível em: http://www1.folha.uol.com.br/folha/ilustrada/ult90u62468.shtml

FREIRE FILHO, João. Mídia, estereótipo e representação das minorias. Rio de Janeiro: Revista Eco-Pós, v. 7, nº 2, agosto a dezembro de 2004, p. 45-71.

FREITAS, Sueli. Resistência Guarani-Kaiowá no Mato Grosso do Sul marca 2012. Portal EBC, 17/12/2012. Disponível em: http://www.ebc.com.br/noticias/retrospectiva2012/2012/12/resistencia-indigena-no-mato-grosso-do-sul-marca-2012. Acessado em 26/01/2017, às 13:40.

FRENTE EM DEFESA DA EBC E DA COMUNICAÇÃO PÚBLICA. Nota pública: Em defesa da Empresa Brasil de Comunicação e da Comunicação Pública. Online. 17 de maio de 2016. Disponível em: http://intervozes.org.br/nota-publica-em-defesa-daempresa-brasil-de-comunicacao-e-da-comunicacao-publical. Acessado em 29/12/2016, às $18 \mathrm{~h} 27$. 
FREUD, Sigmund. Três ensaios sobre a teoria da sexualidade. Rio de Janeiro: Imago, 1973. $108 \mathrm{p}$.

FRÔ, Maria. Denúncia: Censura e Manipulação golpista de Notícias na EBCAgência Brasil. Revista Fórum, online, 25/10/2016. Disponível em: http://www.revistaforum.com.br/mariafro/2016/10/25/denuncia-censura-emanipulacao-golpista-de-noticias-na-ebc-agencia-brasill. Acessado em 30/12/2016, às $17 \mathrm{~h} 08$.

GÊNESIS, IX: 24-25. Disponível em: https://www.bibliaonline.com.br/acf/gn/9. Acessado em 12/11/2015, às 14:56.

GINSBURG, Faye D. Screen memories: resignifying the traditional in indigenous media. In: Media Worlds: Anthropology on New Terrain. , et al. California: University of California Press, 2002, p. $39-57$.

GONÇALVES, Gustavo Soranz. Panorama do documentário no Brasil. Revista Doc On-line, n. 01 Dezembro 2006, p. $79-91$.

GUARESCHI, Pedrinho A. Representações sociais e ideologia. Revista de Ciências Humanas, Florianópolis: EDUFSC, Edição Especial Temática, p.33-46, 2000.

GUERREIRO, Soane Costa. TV Brasil e a Rede Pública de Televisão: uma trajetória de dependência. 2016. 180 f., il. Dissertação (Mestrado em Comunicação) Universidade de Brasília, Brasília, 2016.

HALL, Stuart. The work of representation. In: HALL, Stuart (ed.). Representation: cultural representations and signifying practices. Londres: Sage Publications, 2001, p. 13-64.

IANNI, Octavio. Dialética das relações raciais. Revista Estudos Avançados 18 (50), 2004.

INSTITUTO BRASILEIRO DE GEOGRAFIA E ESTATÍSTICA - IBGE. Censo Populacional: O Brasil Indígena. 2010. Disponível em: http://indigenas.ibge.gov.br/ Acessado em 18/09/2014, às 17:08.

JAKUBASZKO, Daniela. Alma Gêmea: o indígena na telenovela. Trabalho apresentado ao NP Ficção Seriada, do VI Encontro dos Núcleos de Pesquisa do XXIX Congresso de Ciências da Comunicação do Intercom, 2006. Disponível em: http://www.intercom.org.br/papers/nacionais/2006/resumos/r1487-1.pdf

JECUPÉ, Kaká Werá. A terra dos mil povos: história indígena brasileira contada por um índio. São Paulo: Editora Peirópolis, 1998.

JEKUPE, Olívio. A literatura nativa faz com que a sociedade conheça melhor os povos indígenas. Programa Ver TV: 03/11/2015. Entrevista. Disponível em: http://tvbrasil.ebc.com.br/vertv/post/a-literatura-nativa-faz-com-que-a-sociedadeconheca-melhor-os-povos-indigenas. Assistido em: 06/01/2017, às 14:32. 
JODELET, Denise. Representações sociais: um domínio em expansão. In: As Representações Sociais. JODELET, Denise (org.). Editora UERJ: Rio de Janeiro, 2001 , p. $17-44$.

KLEIN, Otávio José. A midiatização no telejornalismo em rede: as reportagens da Rede Brasil Sul de Televisão sobre os indígenas caingangues no Rio Grande do Sul. Tese. São Leopoldo: Programa de Pós-Graduação em Ciências da Comunicação da Universidade do Vale do Rio dos Sinos, 2008.

KLEIN, Tatiane; MILAN, Laine; PANKARU, Dora. Invisibilidade dos indíos: a falta de programas sobre as culturas índígenas na TV. Programa Ver TV: 08/11/2013. Entrevistas concedidas a Lalo Leal. Disponível em: http://tvbrasil.ebc.com.br/vertv/episodio/invisibilidade-dos-indios-a-falta-de-programassobre-as-culturas-indigenas-na-tv Assistido em: 19/09/2014, às 17:32.

LEITE, Marcelo; AMORA, Dimmi; KACHANI, Morris; et al. Tudo sobre a batalha de Belo Monte. Jornal Folha de São Paulo, 16 de dezembro de 2013. Disponível em: http://arte.folha.uol.com.br/especiais/2013/12/16/belo-monte/. Acessado em 26/01/2017, às 13:31.

LISBOA, Vinícius. Sem reforma prometida, Museu do Índio segue abandonado ao lado do Maracanã. Portal da EBC, 04/06/2016. Disponível em: http://agenciabrasil.ebc.com.br/cultura/noticia/2016-06/sem-reforma-prometida-museudo-indio-segue-abandonado-ao-lado-do-maracana. Acessado em 26/01/2017, às 14:32.

LOBO, Narciso Júlio Freire. História e ficção na TV. In: Revista Brasileira de Ciências da Comunicação. São Paulo, v.30, n.1, p. 175-193, jan./jun. 2007.

LOPES, I. S. TV Brasil e a construção da Rede Nacional de Televisão Pública. Jundiaí: Paco Editoral, 2015, 264 p.

LUCIANO, Gersem dos Santos. O Índio Brasileiro: o que você precisa saber sobre os povos indígenas no Brasil de hoje. Série Via dos Saberes nº 1, Coleção Educação para Todos. UNESCO: 2006, 233 p. Disponível em:

http://unesdoc.unesco.org/images/0015/001545/154565por.pdf Último acesso:

08/10/2014, às 10:24.

MACHADO, Arlindo. A televisão levada a sério. São Paulo: Editora Senac São Paulo, $5^{\mathrm{a}}$ ed., 2009.

MARX, Karl. O caráter fetichista da mercadoria e seu segredo. In: O Capital - Crítica da Economia Política. São Paulo: Editora Nova Cultura, v. 1, livro $1^{\circ}$, tomo 1, 1996, p. $197-208$.

MELCHIOR, Marcelo. Gênero, cultura e hibridização no programa A'Uwe da TV Cultura. Salvador, Bahia: Seminário Internacional Análise de Telejornalismo, 23 a 26 de agosto de 2011.

MELO, Patrícia Bandeira de. Sujeitos sem voz: agenda e discurso sobre o índio na mídia em Pernambuco. Dissertação defendida na Universidade Federal de Pernambuco, 2003. 
MINARDI, Deborah. Mídia e Representações Sociais Indígenas: Caso do ataque ao acampamento Guarani Kaiowá. Disponível em

http://www.unicentro.br/redemc/2012/artigos/30.pdf . Acessado em 02/11/2014, às $16: 36$.

MONTEIRO, Tânia. Aliados de Temer pedem extinção da EBC. O Estado de São Paulo, online, 11/12/2016. Disponível em:

http://politica.estadao.com.br/noticias/geral,aliados-de-temer-pedem-extincao-daebc,10000056652. Acessado em 30/12/2016, às 10h.

MOURA, Maria Francisca Canovas de. Telejornal dos 500 anos: Frames de Protesto e Violência. Dissertação. São Leopoldo: Programa de Pós-Graduação em Ciências da Comunicação da Universidade do Vale do Rio dos Sinos, 2001.

MUSEU DO ÍNDIO. Página na internet. Disponível em: http://www.museudoindio.gov.br/. Acessado em 07/02/2017, às 18:41.

NATIONAL INDIGENOUS TELEVISION - NTIT. Disponível em: http://www.nitv.org.au/about-nitv/dsp-default.cfm?loadref=19 Acessado em 21/09/2014, às 14:27.

NOGUEIRA, Oracy. Preconceito racial de marca e preconceito racial de origem. Sugestão de um quadro de referência para a interpretação do material sobre relações raciais no Brasil. São Paulo: Tempo Social, revista de sociologia da USP, v. 19, n. 1, p. 287-308.

NUNES, K. M; SILVA, R. I; SILVA, J. O. S. Cinema indígena: de objeto a sujeito da produção cinematográfica no Brasil. In: Polis, Revista Latinoamericana. Santiago: Volume 13, No 38, 2014, p. 173-204. Disponível em:

http://www.scielo.cl/scielo.php?pid=S0718-65682014000200009\&script=sci_arttext

OLIVEIRA, Mariana. Toffoli revoga liminar que mantinha Ricardo Melo na presidência da EBC. G1, online, 08/09/2016. Disponível em:

http://g1.globo.com/politica/noticia/2016/09/toffoli-revoga-liminar-que-mantinharicardo-melo-na-ebc.html. Acessado em 30/12/2016, às $16 \mathrm{~h} 17$.

ORGANIZAÇÃO DAS NAÇÕES UNIDAS - ONU. Declaração Universal dos Direitos dos Povos Indígenas. 2008. Disponível em:

http://www.dhnet.org.br/direitos/sip/onu/indios/decindio.htm. Acessado em 19/10/2015, às 18:39.

ORLANDI, Eni. Análise de discurso: princípios e perspectivas. Campinas, SP: Pontes, $10^{a}$ ed., 2012.

ORTNER, Sherry. Is female to male as nature is to culture?. In: ROSALDO, M.; LAMPHERE, L. Women, Culture and Society. Stanford: Stanford University Press, 1974, p. 67-87.

PAIVA, Cláudio Cardoso. Epifanias do sublime, do trágico e do maravilhoso na minissérie Hoje é dia de Maria. Unisinos: bocc.ubi.pt. Disponível em:

http://bocc.unisinos.br/pag/paiva-claudio-epifania-do-sublime.pdf 
PAIVA, Samuel. Ao redor do Brasil - cinema como apropriação?. In: MACHADO JR., Rubens, et. al (org). Estudos de Cinema. São Paulo: Annablume, Socine, v. VII, 2006. Disponível em: http://www.socine.org.br/livro/livro.pdf\#page=225

PEREIRA, Marcos Emanoel. Psicologia social dos estereótipos. São Paulo, SP: EPU, 2002.

PERES, João. Lei de Meios na Argentina abre caminho para indígenas resgatarem cultura. [Editorial]. Revista Fórum: 19 de dezembro de 2012. Disponível em: http://www.revistaforum.com.br/blog/2012/12/lei-de-meios-na-argentina-abre-caminhopara-indigenas-resgatarem-cultura/ Acessado em 21/09/2014, às 14:05.

PINTO, Alejandra Aguilar. Identidade/diversidade cultural no ciberespaco: práticas informacionais e de inclusão digital nas comunidades indígenas, o caso dos KaririXocó e Pankararu no Brasil. 2010. xix, 273 f. Tese (Doutorado em Ciência da Informação) - Universidade de Brasília, Brasília, 2010, 292 p. Disponível em: http://hdl.handle.net/10482/7113 Acessado em 08/10/2014, às 13:37.

PIOVESAN, Eduardo. Câmara aprova MP que reestrutura a Empresa Brasil de Comunicação. Câmara Notícias, online, 15/12/2016. Disponível em: http://www2.camara.leg.br/camaranoticias/noticias/COMUNICACAO/521399CAMARA-APROVA-MP-QUE-REESTRUTURA-A-EMPRESA-BRASIL-DECOMUNICACAO.html. Acessado em 30/12/2016, às 17h41.

PORTAL DA REDE GLOBO. Novela Araguaia. Disponível em: http://memoriaglobo.globo.com/programas/entretenimento/novelas/araguaia.htm

PROUS, André. O Brasil antes dos brasileiros. Rio de Janeiro: Zahar, 2a edição, 2006.

REIS, Diogo Alves de Faria. História da formação de professores de matemática do ensino primário em Minas Gerais: estudos a partir do acervo de Alda Lodi (1927 a 1950). Tese de doutoramento. Minas Gerais: Universidade Federal de Minas Gerais, 2014, 258 p.

REPRESENTANTES DE COLETIVOS INDÍGENAS DE PRODUÇÃO

AUDIOVISUAL et al. Carta de Diamantina. 45o Festival de Inverno da Universidade Federal de Minas Gerais: Diamantina, 25 de Julho de 2013. Disponível em: http://www.dialogosdosul.org.br/carta-de-diamantina-dos-coletivos-de-audiovisualindigenas-no-brasil/ Último acesso: 08/10/2014, às 10:37.

RICARDO, Carlos Alberto. Passados 500 anos, nem sabemos seus nomes. In: GRUPIONI, Luís; VIDAL, Lux; FISHMANN, Roselli (org.). Povos indígenas e tolerância: construindo práticas de respeito e solidariedade. São Paulo: Editora da USP, 2001, p. 63-70.

ROTH, Lorna. Something new in the air: The story of First Peoples television broadcasting in Canada. McGill-Queen's Press - MQUP, 2005, 300 p.

SANSI-ROCA, Roger. Feitiço e fetiche no Atlântico moderno. Revista de Antropologia, São Paulo: USP, v. 51, n. 1, 2008, p. 123 - 153. 
SANTOS, Fabiane Vinete dos. Mulheres indígenas, movimento social e feminismo na amazônia: empreendendo aproximações e distanciamentos necessários. Revista EducAmazônia: Ano 5, vol VIII, 2012-1, jan-jun, Pág 94-104

SIAVAYA, Ravel Lara. Xingu: a representação dos índios no filme segundo a teoria da alteridade. Tese de licenciatura. Holanda: Universidade de Utrecht, bloco IV, 2013.

SILVA, Juliano Gonçalves da. Entre o bom e o mau selvagem: ficção e alteridade no cinema brasileiro. In: Revista Espaço Ameríndio, Porto Alegre, v. 1, n. 1, p. 195-210, jul./dez. 2007. Disponível em:

http://www.seer.ufrgs.br/EspacoAmerindio/article/viewFile/2436/1569

SOUSA, Maria de Nazaré Cavalcante de. Traços de interculturalidade na ficção televisiva. XIII Encontro da ABRALIC. Campina Grande, Paraíba: 10 a 12 de outubro de 2012. Disponível em:

http://editorarealize.com.br/revistas/abralic/trabalhos/7c99f50ed692fdf342cde26a8086a $\underline{1 \mathrm{ad} \_330 \_101 \_. p d f}$

SURVIVE. Terminologia. Online. Disponível em: http://www.survivalinternational.org/sobrenos/terminologia. Acessado em: 04/02/2017, às 13:47.

THOMPSON, John B. Ideologia e cultura moderna: teoria social crítica na era dos meios de comunicação de massa. Petrópolis, Rio de Janeiro: Vozes, 1995, 427 p.

TRUFFI, Renan. EBC, a nova obsessão de Temer. Carta Capital, online, 16/09/2016. Disponível em: http://www.cartacapital.com.br/revista/918/ebc-a-nova-obsessao-detemer. Acessado em 30/12/2016, às 16h19.

TV MAORI. Disponível em: http://www.maoritelevision.com/about/about-maoritelevision Acessado em 21/09/2014, às 13:56.

UNESCO. Declaração universal sobre a diversidade cultural. Nova Iorque: UNESCO, 2001b. Disponível em: http://unesdoc.unesco.org/images/0012/001271/127160por.pdf. Acessado em: 03/01/2017, às 14 h25.

. Many voices, one world. Paris, Londres, Nova Iorque: Unesco, 1980.

Radiodifusão pública: por quê? Como?. Nova Iorque: UNESCO, 2001a. UNIVERSIDAD AUTÓNOMA METROPOLITANA. Disponível em: http://sgpwe.izt.uam.mx/. Acessado em 13/11/2015, às 19:03.

UNIVERSIDADE DE SÃO PAULO. Dicionário de tupi antigo. Disponível em http://tupi.fflch.usp.br/node/5. Acessado em 07/02/2017, às 17:24.

VALENTE, Jonas Chagas Lúcio. TV pública no Brasil: a criação da TV Brasil e sua inserção no modo de regulação setorial da televisão brasileira. 2009. vi, 206 f.

Dissertação (Mestrado em Comunicação)-Universidade de Brasília, Brasília, 2009. 
VERONESE, Marília; GUARESCHI, Pedrinho. Hermenêutica de Profundidade na pesquisa social. In: Revista Ciências Sociais Unisinos. São Leopoldo: 42(2):85-93, maio/ago 2006, p. 85 - 93.

VÍDEO NAS ALDEIAS. Disponível em:

http://www.videonasaldeias.org.br/2009/vna.php?p=1. Acessado em 28/09/2016, às $14: 43$.

VILLAÇA, Nízia. A cultura do fetiche: corpo e moda. XXVII Congresso Brasileiro de Ciências da Comunicação. Porto Alegre: 2004. Disponível em: http://www.portcom.intercom.org.br/pdfs/9527176592165449502480026938361160176 7.pdf. Acessado em 09/02/2016, às 17:50.

WADE, Peter. Raza y etnicidad en latinoamérica. Quito: Ecuador, Ediciones AbyaYala, 2000. 